\begin{tabular}{|c|l|}
\hline Title & $\begin{array}{l}\text { Changes in activity and transcript level of liver and gill metabolic enzymes during smoltification in wild and hatchery- } \\
\text { reared masu salmon (Oncorhynchus masou) }\end{array}$ \\
\hline Author(s) & $\begin{array}{l}\text { Mizuno, Shinya; Urabe, Hirokazu; A oyama, Tomoya; Omori, Hajime; Iijima, A nai; Kasugai, Kiyoshi; Torao, Mitsuru; } \\
\text { Misaka, Naoyuki; Koide, Nobuhisa; Ueda, Hiroshi }\end{array}$ \\
\hline Citation & $\begin{array}{l}\text { Aquaculture, 362-363, 109-120 } \\
\text { https://doi.org/10.1016/.aquaculture.2010.10.034 }\end{array}$ \\
\hline Issue Date & 2012-09-28 \\
\hline Doc URL & http://hdl.handle.net/2115/50686 \\
\hline Type & article (author version) \\
\hline File Information & A qu362-363_109-120.pdf \\
\hline
\end{tabular}

Instructions for use 


\section{Changes in activity and transcript level of liver and gill metabolic enzymes during smoltification in wild and hatchery-reared masu salmon (Oncorhynchus masou)}

Shinya Mizuno ${ }^{1 *}$, Hirokazu Urabe ${ }^{1}$, Tomoya Aoyama ${ }^{1}$, Hajime Omori ${ }^{2}$, Anai Iijima ${ }^{2}$, Kiyoshi Kasugai ${ }^{3}$, Mitsuru Torao ${ }^{3}$, Naoyuki Misaka ${ }^{4}$, Nobuhisa Koide ${ }^{1}$ and Hiroshi Ueda $^{5}$

${ }^{1}$ Salmon and Freshwater Fisheries Research Institute, Hokkaido Research Organization, Eniwa, Hokkaido, 061-1433 Japan.

${ }^{2}$ Donan Research Branch of Salmon and Freshwater Fisheries Research Institute, Yakumo, Hokkaido, 043-0402 Japan

${ }^{3}$ Doto Research Branch of Salmon and Freshwater Fisheries Research Institute, Nakashibetsu, Hokkaido, 086-1164 Japan

${ }^{4}$ Fisheries Research Department, Hokkaido Research Organization, Yoichi, Hokkaido, 046-8555 Japan

${ }^{5}$ Graduate School of Environmental Science, Hokkaido University, Sapporo, Hokkaido 060-0809, Japan

Running title: Changes in metabolic enzymes during smoltification

*Corresponding author

Shinya Mizuno

Salmon and Freshwater Fisheries Research Institute, Hokkaido Research Organization, Eniwa, Hokkaido, 061-1433 Japan

Tel: +81-123-32-2138

Fax: +81-123-34-7233

E-mail: mizuno-shinya@hro.or.jp 


\begin{abstract}
It is important for success of the masu salmon, Oncorhynchus masou, stock enhancement program in Hokkaido (northern Japan) to demonstrate physiological problems in hatchery-reared (hatchery) smolt for artificial release. The present study examined changes in liver and gill metabolic parameters in wild and hatchery masu salmon during smoltification and elucidated differences in hepatic and gill metabolism between wild and hatchery fish. As reference to freshwater-adapted wild and hatchery smolt in this study, metabolic parameters of coastal smolt were studied. Yearling wild and hatchery smolting fish were collected from the Ken-ichi River and the Donan Research Branch, which used Ken-ichi river water for fish culture, at the same time every month from March through May, 2008. Coastal smolts were caught from Nemuro Bay of Hokkaido in June. Decreased hepatic glycogen content during smoltification, which was observed in wild fish and revealed activation of glycogenolysis, was not found in hatchery fish. Hatchery fish demonstrated a positive change in hepatic ATP content during smoltification, while wild fish showed negative change in the content, which reflected activated consumption of hepatic ATP stores during smoltification. Increases in gill pyruvate kinase activity during smoltification, which were found in wild fish and indicated activation of glycolysis, were not detected in hatchery fish. There was a difference in increased timing of hepatic citrate synthase activity during smoltification between hatchery and wild fish. Increased gill citrate synthase activity during smoltification, which was observed in wild fish and reflected enhancement of the citric acid cycle, was not found in hatchery fish. Hatchery smolt revealed lower liver cytochrome $c$ oxidase activity and transcript levels of some respiratory chain enzymes compared to wild smolt in May, which suggested lower respiratory chain capacity in hatchery fish at mid-smolt stage. On the other hand, there were no remarkable differences in hepatic and gill 3-hydroxyacyl-coenzyme A dehydrogenase related to lipolysis and creatine kinase activities, which operate in resolution of creatine phosphate, during smoltification between hatchery and wild fish. These results suggested hatchery masu salmon had some metabolic problems with carbohydrate metabolism, the citric acid cycle and the respiratory chain. Our study will give valuable information to improve physiological quality of hatchery smolt for artificial release.
\end{abstract}

Key words: Metabolic enzyme, Smoltification, Masu salmon, Liver, Gill 


\section{Introduction}

Masu salmon (Oncorhynchus masou), which are distributed in the western Pacific countries, are an important coastal fishery resource in Hokkaido, northern Japan. In Hokkaido, almost all anadromous masu salmon undergo smoltification, which is a complex of physiological and biochemical changes to be adaptive for life under seawater, and downstream-migration in spring at age 1. Artificial propagation, primarily through release of yearling hatchery-reared (hatchery) smolts into the river, has been conducted as a stock enhancement program for masu salmon, but the coastal masu salmon stock does not show consistent increases in northern Japan. Success of the propagation depends on releasing hatchery smolt with high physiological quality. In hatchery smolts, which are produced at the Hokkaido Fish Hatchery, seawater adaptability is as high as wild smolts (Mizuno et al. 2004). Therefore, it is necessary to clarify if other physiological problems exist in hatchery smolts that may impact smolt success.

Changes in metabolism during smoltification and transfer from freshwater to seawater have been demonstrated in metabolic enzyme activity, the amount of metabolites and metabolic rate in Atlantic salmon (Salmo salar), coho salmon ( $O$. kisutch), chinook salmon (O. tshawytscha) and rainbow trout (O. mykiss). In Atlantic salmon, standard and active metabolic rate is higher in smolts compared to parr (Maxime et al. 1989). Atlantic salmon smolts have lower hepatic and muscle glycogen (GC) and increased blood glucose (GL) level compared with parr (Wendt and Saunders, 1973). Sheridan et al. (1985) demonstrated that decreased hepatic GC content was caused by a combination of reduced GC synthesis and increased glycogenolysis in coho salmon smolts. Muscle phosphofructokinase activity, a glycolytic enzyme, was elevated during smoltification in Atlantic salmon (Leonard and McCormick, 2001). The activities of several key enzymes of glycolysis increase during adaptation from freshwater to seawater in the gill, liver and muscle of large rainbow trout (Soengas et al., 1995a, 1995b, 1995c). Total body and muscle lipid content decreased during smoltification in Atlantic salmon (Saunders and Henderson, 1978). Lipid depletion during smoltification depends on increased lipolysis and decreased fatty acid synthesis in coho and chinook salmon (Sheridan et al. 1985; Sheridan 1988; Cowley et al. 1994). Citrate synthase activity, a citric acid cycle enzyme, of liver, gill and kidney was enhanced during smoltification in Atlantic salmon (McCormick et al., 1989b), but it did not change during seawater transfer (McCormick et al., 1989a). In the gill and liver, activity of respiratory enzymes increased during smoltification in Atlantic salmon (Langdon and Thorpe, 1985; McCormick and Saunders 1987). However, there was 
little information on metabolism of masu salmon smolt, on metabolism of seawater-adapted smolt, and on gene expression of metabolic enzymes in smolts. The present study examined the activity and transcript level of several metabolic enzymes in wild and hatchery juveniles during smoltification and coastal smolt in masu salmon.

\section{Materials and methods}

Fish

Yearling smolting wild masu salmon were collected by electrofishing (Model 12-B Backpack Electrofisher, Smith-Root, Vancouver, BC, Canada) in the Hiyamizu Stream, which is tributary of the Ken-ichi River, in southwestern Hokkaido on March $4\left(4.6{ }^{\circ} \mathrm{C}\right)$, April $3\left(5.3{ }^{\circ} \mathrm{C}\right)$ and May $1\left(9.8^{\circ} \mathrm{C}\right), 2008$. There were no hatchery fish in the Hiyamizu Stream from February 8 to May 1, because release of the hatchery smolts was performed on May 2, 2008. Yearling hatchery smolting juveniles were captured using electrofishing in the Donan Research Branch of Hokkaido Fish Hatchery, which utilizes water from the Ken-ichi River for fish culture, on the same time schedule as collection of smolting wild fish. Smolt phase (Kato, 1991) of both wild and hatchery masu salmon in March, April and May were characterized as parr, pre-smolt and mid-smolt, respectively. Coastal smolts, i.e. post-smolts, were captured by two-boat surface trawling in Nemuro Bay of eastern Hokkaido at latitude $43^{\circ} 31^{\prime} \mathrm{N}, 145^{\circ} 19^{\prime}$ E on June 4, 2008 , since it was accepted that hatchery smolts released from the Ken-ichi River in May had previously been observed in the Nemuro Bay in early June. However, it is unknown whether the captured fish are of hatchery or wild origin. Water temperature and salinity at the coastal smolt sampling were $9.7{ }^{\circ} \mathrm{C}$ and $32 \%$, respectively.

\section{Sampling}

Captured fish were measured for fork length (FL) and body weight (BW) after anesthesia using $300 \mathrm{mg} / \mathrm{L}$ 2-phenoxyethanol. Condition factor $(\mathrm{CF})$ was calculated as $\mathrm{CF}=100 \times \mathrm{BW}(\mathrm{g}) / \mathrm{FL}(\mathrm{cm})^{3}$. Blood was collected using a $1.5 \mathrm{~mL}$ test tube by decaudation in smolting wild and hatchery fish except for coastal smolts. In sampling of coastal smolts, blood was rejected after removing the tail. Serum was separated from blood by centrifugation at $1.0 \times 10^{4} \mathrm{rpm}$ for $15 \mathrm{~min}$ at $4{ }^{\circ} \mathrm{C}$ and frozen at $-85^{\circ} \mathrm{C}$ until serum GL analysis. The entire gill arch assembly on both the right and left sides and the whole liver were sampled after blood sampling and all tissues except for the first gill arch on the left side were frozen at $-85^{\circ} \mathrm{C}$. Gill lamellae were removed from the first gill arch on the left side, and frozen and preserved in SEI buffer $(0.3 \mathrm{~mol} / \mathrm{L}$ sucrose, $20 \mathrm{mmol} / \mathrm{L}$ EDTA, $0.1 \mathrm{mmol} / \mathrm{L}$ imidazole) at $-85{ }^{\circ} \mathrm{C}$ for analysis of 
$\mathrm{Na}^{+}, \mathrm{K}^{+}$-ATPase activity.

Assays

The assay for gill $\mathrm{Na}^{+}, \mathrm{K}^{+}$-ATPase activity was routinely performed using 96 well-microplates according to the method of Riley et al. (2008). In brief, the first gill arch on the left side was homogenized in $750 \mu \mathrm{L}$ of SEI buffer with deoxycholic acid $(2.41 \mathrm{mmol} / \mathrm{L})$ and centrifuged at $2.5 \times 10^{3} \mathrm{rpm}$ for $8 \mathrm{~min}$. Ten $\mu 1$ samples were run in two triplicate sets: one set containing assay mixture and the other assay mixture and $0.72 \mathrm{mmol} / \mathrm{L}$ ouabain. After reaction for $10 \mathrm{~min}$ at $37^{\circ} \mathrm{C}$, released inorganic phosphate $(\mathrm{Pi})$ was determined spectrophotometrically at $630 \mathrm{~nm}$ using microplate reader (Tosou, Tokyo, Japan). The resulting ouabain-sensitive ATPase activity was expressed as $\mu \mathrm{mol}$ Pi per mg protein per hour. Protein concentrations were determined with the BCA protein assay kit (Pierce, Rockford, IL, USA).

Serum was used for determination of GL concentration using commercial GL test kits according to the mutarotase-GOD method (Wako Pure Chemical, Osaka, Japan). Assays for liver GC and triglyceride (TG) content were performed according to Misaka et al. (2004). A piece of sampled liver for GC analysis was homogenized in heated $30 \%(\mathrm{w} / \mathrm{v})$ potassium hydroxide, added to ethanol and centrifuged at $2.5 \times 10^{3} \mathrm{rpm}$ for $20 \mathrm{~min}$ at $4{ }^{\circ} \mathrm{C}$. The precipitate, which was added to $2 \mathrm{~mol} / \mathrm{L} \mathrm{HCl}$ and $1 \mathrm{~mol} / \mathrm{L} \mathrm{H} 2 \mathrm{SO} 4$ in turn, was heated for $2 \mathrm{~h}$ to decompose GC into GL. After the heated sample was centrifuged at $2.5 \times 10^{3} \mathrm{rpm}$ for $20 \mathrm{~min}$ at $4{ }^{\circ} \mathrm{C}$, GL content of the supernatant was analyzed using the GL test kit (Wako Pure Chemical) and expressed as percentage of GC content/liver (w/w). A piece of liver sample was homogenized with ethanol/diethyl ether $(3: 1, \mathrm{v} / \mathrm{v})$ and centrifuged at $2.5 \times 10^{3} \mathrm{rpm}$ for $20 \mathrm{~min}$ at $4{ }^{\circ} \mathrm{C}$. TG content of the supernatant was examined using TG test kit (Wako Pure Chemical) and shown as percentage of TG content/liver (w/w).

For ATP content and metabolic enzyme assays, a part of liver and the first gill arch on the right side were homogenized with ice-cold 20 volumes homogenization buffer ( 5 mmol/L HEPES, 1 mmol/L EDTA, 0.01\% Triton X-100, pH 7.4). Homogenates were then centrifuged at $1.5 \times 10^{4} \mathrm{rpm}$ for $20 \mathrm{~min}$ and the supernatants were used for assays. ATP content analysis was performed according to Burness et al. (2005).

Luciferin-luciferase (dissolved in $100 \mathrm{mmol} / \mathrm{L}$ glycine, $20 \mathrm{mmol} / \mathrm{L} \mathrm{MgSO} 4, \mathrm{pH}$ 7.4) was added to the sample. Total amount of luminous intensity for 5 min was measured using luminescence reader (BLR310, Aloka, Tokyo, Japan). The ATP standard ranged between $10^{-16} \mathrm{~mol} / \mathrm{L}$ and $10^{-8} \mathrm{~mol} / \mathrm{L}$. ATP content was expressed as pmol ATP per $\mathrm{g}$ wet tissue. 
Metabolic enzyme assayed at $25{ }^{\circ} \mathrm{C}$ using UV/Visible spectrophotometer (Ultrospec 2000; GE Heathcare UK, Buckinghamshire, UK) under the following specific condition, which referred to Moyes et al. (1997) and Burness et al. (2005).

Pyruvate kinase (PRK): The assay contained $5 \mathrm{mmol} / \mathrm{L} \mathrm{ADP,} 100 \mathrm{mmol} / \mathrm{L} \mathrm{KCl}, 10$ $\mathrm{mmol} / \mathrm{L} \mathrm{MgCl} 2,0.15 \mathrm{mmol} / \mathrm{L} \mathrm{NADH}, 10 \mu \mathrm{mol} / \mathrm{L}$ fructose-1,6-bisphosphate, $5 \mathrm{mmol} / \mathrm{L}$ phosphoenolpyruvate, and excess lactate dehydrogenase (free of PRK) in $50 \mathrm{mmol} / \mathrm{L}$ 3-(N-morpholino) propanesulfonic acid (MOPS; pH 7.4). The assay was started with enzyme at $340 \mathrm{~nm}$, but was strictly dependent on phosphoenolpyruvate.

3-Hydroxyacyl-coenzyme A (CoA) dehydrogenase (HOAD): The assay contained 0.1 $\mathrm{mmol} / \mathrm{L}$ acetoacetyl CoA, $0.15 \mathrm{mmol} / \mathrm{L} \mathrm{NADH}$ and $0.05 \%$ Triton $\mathrm{X}-100$ in $50 \mathrm{mmol} / \mathrm{L}$ PIPES (pH 7.0). The assay was started by addition of enzyme at $340 \mathrm{~nm}$, and no NADH oxidation was evident in the acetoacetyl CoA.

Creatine phosphokinase (CRK): The assay contained $50 \mathrm{mmol} / \mathrm{L}$ creatine phosphate, $1 \mathrm{mmol} / \mathrm{L}$ ADP, $0.5 \mathrm{mmol} / \mathrm{L} \mathrm{NADP}^{+}, 5 \mathrm{mmol} / \mathrm{L}$ glucose, $10 \mathrm{mmol} / \mathrm{L}$ AMP and $5 \mathrm{mmol} / \mathrm{L}$ $\mathrm{MgCl} 2$ and excess hexokinase and glucose-6-phosphate dehydrogenase in $20 \mathrm{mmol} / \mathrm{L}$ MOPS (pH 7.4). This assay was performed at $340 \mathrm{~nm}$.

Citrate synthase (CS): The assay contained in $0.1 \mathrm{mmol} / \mathrm{L}$ 5,5'-dithio-bis-(2-nitrobenzoic acid), $0.3 \mathrm{mmol} / \mathrm{L}$ acetyl CoA and $0.5 \mathrm{mmol} / \mathrm{L}$ oxaloacetate in $50 \mathrm{mmol} / \mathrm{L}$ Tris- $\mathrm{HCl}(\mathrm{pH} \mathrm{8.0)}$. The increase in absorbance at a wavelength of $412 \mathrm{~nm}$ was measured with a reference cuvette lacking oxaloacetate to correct for background thiolase activity.

Lactate dehydrogenase (LDH): The assay contained $0.15 \mathrm{mmol} / \mathrm{L} \mathrm{NADH,} 0.2$ $\mathrm{mmol} / \mathrm{L}$ pyruvate in $20 \mathrm{mmol} / \mathrm{L}$ HEPES ( $\mathrm{pH} 7.0$ ). This assay was run without control at $340 \mathrm{~nm}$, since the controls showed less activity.

Cytochrome $c$ oxidase (COX): The assay contained $50 \mu \mathrm{mol} / \mathrm{L}$ reduced cytochrome $c$ and $0.5 \%$ Tween 20 in $20 \mathrm{mmol} / \mathrm{L}$ Tris- $\mathrm{HCl}(\mathrm{pH} \mathrm{8.0)}$. Cytochrome $c$ was reduced with ascorbate, dialyzed exhaustively in Tris- $\mathrm{HCl}(\mathrm{pH} 8.0)$, and stored at $-80{ }^{\circ} \mathrm{C}$. The concentration was determined with an extinction coefficient of $28.5 \mathrm{mmol} / \mathrm{L}$ at $550 \mathrm{~nm}$. The enzyme extract was added 4 min before addition of cytochrome $c$ (shorter preincubations resulted in lower activities).

One unit $(\mathrm{U})$ of all metabolic enzyme activities represented $1 \mu \mathrm{mol}$ of substrate converted to product per minute. These activities were expressed as units per mg protein.

Transcript levels of subunits of mitochondrial enzymes, NADH dehydrogenase subunit 1 (NDH1), COX subunit 1(COX1) and ATP synthase subunit 8 (ATS), were analyzed using competitive polymerase chain reaction (PCR) described in Mizuno et al. 
(2008). In brief, total RNA was extracted from a section of liver and the second gill arch on the left side using Isogen (Wako Pure Chemical) and contaminating genomic DNA was removed by deoxyribonuclease I (Wako Pure Chemical) treatment. cDNA was synthesized from $0.15 \mu \mathrm{g}$ total RNA with random hexanucleotide primers (Invitrogen, Carlsbad, CA, USA) and M-MLV reverse transcriptase (Invitrogen) in 10 $\mu \mathrm{l}$ reaction. Reverse transcription was done at $37^{\circ} \mathrm{C}$ for $60 \mathrm{~min}$ and then inactivated for $5 \mathrm{~min}$ at $75^{\circ} \mathrm{C}$. The forward and reverse primers for competitive PCR were designed based on the complete mitochondrial DNA sequence of rainbow trout (Zardoya et al. 1995), Atlantic salmon (GenBank accession no. NC001960) and cutthroat trout (GenBank accession no. NC006897) (Table 1). PCR products, which were originated from partial nucleotide sequences of NDH1, COX1 and ATS, amplified using these primers were 205, 246 and $170 \mathrm{bps}$, respectively. A competitor, an internal standard for competitive PCR, was amplified by PCR using the forward primer and competitor-making primer with liver cDNA. The competitor-making primer was designed as a 17 to 21 nucleotide sequence coded into the nucleotide sequence of the partial target enzyme between the forward and the reverse primer (Table 1). The competitor was cloned using TA Cloning Kit (Invitrogen). Prior to use of the internal standard of competitive PCR, the recombinant plasmid PCR 2.1 vector was digested using EcoR1 (Nippon Gene, Toyama, Japan) and the insert fragment was purified using QIAquick Gel Extraction Kit (Qiagen, Valencia, CA, USA). Competitive PCR was performed for 30 cycles $\left[94{ }^{\circ} \mathrm{C}\right.$ for $1 \mathrm{~min}$ as denature; $51.5{ }^{\circ} \mathrm{C}(\mathrm{NDH} 1), 50.6{ }^{\circ} \mathrm{C}$ (COX1) and $54.9^{\circ} \mathrm{C}$ (ATS) for $1 \mathrm{~min}$ as annealing; $72{ }^{\circ} \mathrm{C}$ for $1 \mathrm{~min}$ as extension]. The reaction mixture contained $0.5 \mu \mathrm{l}$ cDNA, various amount of the $1.0 \mu \mathrm{l}$ competitor, 2.5 $\mathrm{pmol} / \mathrm{L}$ forward and reverse primers, $2.5 \mathrm{nmol} / \mathrm{L}$ dNTPs and 0.062 units of Taq DNA polymerase (Gene Taq; Nippon Gene) in a final volume of $12.5 \mu \mathrm{l}$. The $5 \mu \mathrm{l}$-PCR samples were separated by electrophoresis through $2 \%$ agarose gels containing $1 \mathrm{mg} / \mathrm{L}$ ethidium bromide. Black and white photographs (FP-3000B; Fuji Film, Tokyo, Japan) of the gels were taken through a transilluminator and scanned by image scanner (Color Imaging GT-7600U; Epson, Tokyo, Japan). The intensity of two bands originated from the competitor and target enzyme on the negative film was quantified using the NIH Image version 1.59 analysis system. The intensity ratio of the target enzyme/competitor was plotted against the amount of added competitor. Transcript level of target enzyme was determined, when intensity of target enzyme band is equal to the competitor band and expressed as relative competitor amount (mol) per $\mu \mathrm{g}$ total RNA. 


\section{Statistical analysis}

One-way analysis of variance followed by Fisher's protected least significant difference as post hoc test were conducted to examine changes in a variety of parameters during smoltification (March to May) in the Ken-ichi River wild (K-wild) and hatchery fish. Kruskal-Wallis test was used to compare parameters among K-wild smolt, hatchery smolt in May and coastal smolt in June. Comparison in parameters between K-wild and hatchery fish in March and April was performed using Student's t-test. Significant difference was found when $\mathrm{p}<0.05$.

\section{Results}

Body size and $C F$

Table 2 showed FL, BW and CF of fish used in our study. There was no significant difference in either FL and BW between K-wild and hatchery fish from March to May. Reduced CF during smoltification was detected from April to May in K-wild fish ( $\mathrm{p}=$ 0.030), but it was not detected in hatchery fish.

\section{Gill $\mathrm{Na}^{+}, \mathrm{K}^{+}$-ATPase activity}

Gill $\mathrm{Na}^{+}, \mathrm{K}^{+}$-ATPase activity enhanced from March to May in K-wild ( $\mathrm{p}<0.0001$ ) and hatchery smolting fish $(\mathrm{p}<0.0001)$ (Fig. 1). No difference was observed in $\mathrm{Na}^{+}$, $\mathrm{K}^{+}$-ATPase activity between K-wild and hatchery fish from March to May. Coastal smolt showed higher $\mathrm{Na}^{+}, \mathrm{K}^{+}$-ATPase activity compared to $\mathrm{K}$-wild $(\mathrm{p}=0.022)$ and hatchery smolts $(\mathrm{p}<0.0001)$ in May.

\section{Serum GL concentration and hepatic GC and TG content}

Serum GL concentration reduced from March $(6.73 \pm 0.60 \mathrm{mmol} / \mathrm{L})$ to April $(4.31 \pm$ $0.35 \mathrm{mmol} / \mathrm{L}$ ) in $\mathrm{K}$-wild fish ( $\mathrm{p}<0.0001$ ), whereas it did not change during smoltification in hatchery fish (Fig. 2). Liver GC content reduced from March (1.54 \pm $0.19 \%)$ to April $(0.64 \pm 0.07 \%)$ in K-wild fish ( $<$ < 0.0001) (Fig. 2). However, the GC reduction during smoltification was not found in hatchery fish. K-wild fish had higher liver GC content $(257 \%)$ than hatchery fish in March ( $<<0.0001)$. Coastal smolts $(0.36 \pm 0.05 \%)$ showed smaller GC content compared to K-wild smolts $(0.74 \pm$ $0.05 \%$; $\mathrm{p}<0.0001)$ in May. Liver TG content significantly decreased from March to April in K-wild (61\%; $\mathrm{p}<0.0001)$ and hatchery fish (56 \%; $\mathrm{p}<0.0001)$ (Fig. 3). There was no difference in TG between K-wild and hatchery smolt in March through May. 


\section{ATP content}

K-wild fish showed declines in the liver ATP content $(\mathrm{p}<0.0001)$ from March $(313.9$ $\pm 108.0 \mathrm{pmol} / \mathrm{g}$ liver $)$ to May $(20.0 \pm 5.12 \mathrm{pmol} / \mathrm{g}$ liver $)$, while the content increased from March (30.5 $\pm 8.52 \mathrm{pmol} / \mathrm{g}$ liver) to May (1163.6 $\pm 681.8 \mathrm{pmol} / \mathrm{g}$ liver $)$ in hatchery fish ( $\mathrm{p}<0.0001)$ (Fig. 4). The liver ATP of hatchery fish was higher than K-wild fish in April ( $\mathrm{p}=0.028)$ and May $(\mathrm{p}<0.0001)$. Hepatic ATP content of coastal smolts was lower than that of hatchery smolts in May $(\mathrm{p}<0.0001)$. Gill ATP content increased from March (155.5 $\pm 44.3 \mathrm{pmol} / \mathrm{g}$ gill) to April $(336.9 \pm 48.8 \mathrm{pmol} / \mathrm{g}$ gill $)$ in K-wild fish $(\mathrm{p}=0.025)$. However, no significant change during smoltification was not observed in the gill ATP content in hatchery fish.

\section{PRK activity}

Liver PRK activity of K-wild fish increased from March $(1.94 \pm 0.15 \mathrm{U} / \mathrm{mg}$ protein $/ \mathrm{min})$ to April $(3.43 \pm 0.53 \mathrm{U} / \mathrm{mg}$ protein $/ \mathrm{min})(\mathrm{p}=0.012)$ and did not change from April through May (3.43 $\pm 0.35 \mathrm{U} / \mathrm{mg}$ protein/min) (Fig.5). This activity of hatchery fish rose from March $(1.00 \pm 0.08 \mathrm{U} / \mathrm{mg}$ protein/min) to April $(3.61 \pm 0.27$ $\mathrm{U} / \mathrm{mg}$ protein/min) $(\mathrm{p}<0.0001)$ and thereafter it declined from April to May $(1.90 \pm$ $0.12 \mathrm{U} / \mathrm{mg}$ protein/min) $(\mathrm{p}<0.0001)$. K-wild fish showed higher hepatic PRK activity compared to hatchery fish in March $(\mathrm{p}=0.003)$ and May $(\mathrm{p}<0.0001)$. Liver PRK activity of coastal smolts was significantly higher than the activity of K-wild (174\%; $\mathrm{p}$ $<0.0001)$ and hatchery smolts in May (315\%; $<0.0001)$. In the gill, PRK activity rose from March $(5.81 \pm 0.53 \mathrm{U} / \mathrm{mg}$ protein $/ \mathrm{min})$ to May $(8.13 \pm 0.58 \mathrm{U} / \mathrm{mg}$ protein/min) in K-wild fish ( $\mathrm{p}<0.0001)$, while there was no significant change in the activity during smoltification in hatchery fish (Fig. 5). Gill PRK activity of coastal smolts was equal to the activity of K-wild and hatchery smolts in May.

\section{HOAD activity}

No significant changes in hepatic HOAD activity from March to May were found in either K-wild or hatchery fish (Fig. 6). There was no difference in the activity between K-wild and hatchery fish in April or May. Coastal smolts showed higher hepatic HOAD activity compared to K-wild ( $\mathrm{p}$ 0.0001) and hatchery smolts in May ( $<$ 0.0001). Gill HOAD activity showed no changes from March to May in either K-wild or hatchery fish (Fig. 6). No significant difference was found in the activity between K-wild and hatchery fish in March to May. Gill HOAD activity of coastal smolts (3.37 $\pm 0.25 \mathrm{U} / \mathrm{mg}$ protein $/ \mathrm{min}$ ) was higher than the activity of K-wild $(1.96 \pm 0.19 \mathrm{U} / \mathrm{mg}$ protein/min; $\mathrm{p}<0.0001)$ and hatchery smolts $(1.85 \pm 0.09 \mathrm{U} / \mathrm{mg}$ protein/min; $\mathrm{p}<$ 
$0.0001)$ in May.

\section{CRK activity}

Liver CRK activity increased from March $(2.97 \pm 0.36 \mathrm{U} / \mathrm{mg}$ protein/min) to May $(4.81 \pm 0.60 \mathrm{U} / \mathrm{mg}$ protein/min) in K-wild fish $(\mathrm{p}=0.032)($ Fig. 7$)$. There was no difference in the CRK activity between K-wild and hatchery fish from March to May. Coastal smolts (48.9 $\pm 6.02 \mathrm{U} / \mathrm{mg}$ protein/min) revealed higher hepatic CRK activity compared to K-wild $(1010 \%$; $p<0.0001)$ and hatchery smolts $(1210 \%$; $p<0.0001)$ in May. In the gill, CRK activity of K-wild fish rose $(p=0.023)$ from April $(6.82 \pm 1.86$ $\mathrm{U} / \mathrm{mg}$ protein) to May (11.0 $\pm 0.68 \mathrm{U} / \mathrm{mg}$ protein) (Fig. 7). No difference was observed in the activity from March to May between K-wild and hatchery fish. Gill CRK activity of coastal smolts was significantly higher than the activity of K-wild $(248 \% ; \mathrm{p}<0.0001)$ and hatchery smolts $(310 \% ; \mathrm{p}<0.0001)$ in May.

\section{CS activity}

Increased hepatic CS activity during smoltification was found in K-wild fish ( $\mathrm{P}<$ $0.0001)$ from March $(0.77 \pm 0.06 \mathrm{U} / \mathrm{mg}$ protein $/ \mathrm{min})$ to May $(1.28 \pm 0.09 \mathrm{U} / \mathrm{mg}$ protein $/ \mathrm{min})$ and in hatchery fish $(\mathrm{P}=0.008)$ from March $(0.56 \pm 0.03 \mathrm{U} / \mathrm{mg}$ protein $/ \mathrm{min})$ to April $(0.96 \pm 0.12 \mathrm{U} / \mathrm{mg}$ protein/min) (Fig. 8). Liver CS activity of $\mathrm{K}$-wild fish was higher than the activity of hatchery fish in March $(136 \% ; \mathrm{p}=0.021)$ and May (149\%; $<$ < 0.0001). Coastal smolts revealed higher hepatic CS activity $(158 \%)$ than hatchery smolt in May $(\mathrm{p}<0.0001)$, while there was no difference in the activity between coastal and K-wild smolts in May. Gill CS activity increased from March $(1.84 \pm 0.06 \mathrm{U} / \mathrm{mg}$ protein/min) to May $(2.12 \pm 0.07 \mathrm{U} / \mathrm{mg}$ protein $/ \mathrm{min})$ in $\mathrm{K}$-wild fish $(\mathrm{p}=0.014)$, while it did not change during smoltification in hatchery fish (Fig. 8). No significant difference was found in the activity from March to May between K-wild and hatchery fish. Coastal smolts showed higher gill CS activity compared to hatchery smolts in May (125\%; $\mathrm{p}=0.036)$, although there was no difference in the activity between coastal and K-wild smolts in May.

\section{LDH activity}

K-wild fish showed reduced liver LDH activity from March $(143.4 \pm 7.87 \mathrm{U} / \mathrm{mg}$ protein/min) to May $(111.05 \pm 3.62 \mathrm{U} / \mathrm{mg}$ protein/min; p < 0.0001) (Fig. 9). On the other hand, LDH activity of hatchery fish rose from March $(59.3 \pm 4.67 \mathrm{U} / \mathrm{mg}$ protein/min) to April $(122.6 \pm 9.89 \mathrm{U} / \mathrm{mg}$ protein/min; $<$ < 0.0001) and then decreased from April to May $(61.6 \pm 5.79 \mathrm{U} / \mathrm{mg}$ protein; $\mathrm{p}<0.0001)$. Coastal smolts $(88.3 \pm$ 
$5.59 \mathrm{U} / \mathrm{mg}$ protein/min; $\mathrm{p}<0.0001$ ) showed lower LDH activity compared to K-wild smolts in May $(111.0 \pm 3.62 \mathrm{U} / \mathrm{mg}$ protein/min). Gill LDH activity did not change from March to May in K-wild and hatchery fish (Fig. 9). Coastal smolts (17.8 \pm 1.69 $\mathrm{U} / \mathrm{mg}$ protein/min) showed lower gill $\mathrm{LDH}$ activity compared to K-wild (32.7 \pm 1.90 $\mathrm{U} / \mathrm{mg}$ protein/min; $\mathrm{p}<0.0001)$ and hatchery smolts $(34.5 \pm 3.75 \mathrm{U} / \mathrm{mg}$ protein/min; $\mathrm{p}<$ $0.0001)$ in May.

\section{COX activity}

Liver COX activity rose from March $(1.09 \pm 0.13 \mathrm{U} / \mathrm{mg}$ protein/min) to May $(2.14 \pm$ $0.24 \mathrm{U} / \mathrm{mg}$ protein/min) in K-wild fish ( $<$ 0.0001) (Fig. 10). Hepatic COX activity of $\mathrm{K}$-wild fish was higher than the activity of hatchery fish in March $(\mathrm{p}=0.014)$ and May $(\mathrm{p}<0.0001)$. Coastal smolts revealed higher hepatic COX activity $(214 \%)$ compared to hatchery fish in May $(\mathrm{p}<0.0001)$, but there was no difference in the activity between coastal and K-wild smolts in May. In the gill, COX activity increased from March $(2.15 \pm 0.27 \mathrm{U} / \mathrm{mg}$ protein $/ \mathrm{min})$ to May $(4.68 \pm 0.20 \mathrm{U} / \mathrm{mg}$ protein $/ \mathrm{min})$ in $\mathrm{K}$-wild fish ( $\mathrm{p}<0.0001$ ) (Fig. 10). Coastal smolts showed equal gill COX activity to K-wild and hatchery smolts in May.

\section{NDH1 transcript level}

Increased hepatic NDH1 transcript level was found from March $(0.40 \pm 0.002 \mathrm{pmol}$ competitor/ $\mu$ g total RNA) to May $(0.52 \pm 0.012 \mathrm{pmol}$ competitor/ $\mu \mathrm{g}$ total RNA) in K-wild fish $(\mathrm{p}<0.0001)$ and from March $(0.42 \pm 0.005 \mathrm{pmol}$ competitor/ $\mu$ g total RNA) to April ( $0.46 \pm 0.004 \mathrm{pmol}$ competitor/ $\mu \mathrm{g}$ total RNA) in hatchery fish ( $\mathrm{p}<0.0001)$ (Fig. 11). K-wild fish revealed higher hepatic NDH1 transcript level compared to hatchery fish in May ( $p=0.0012)$. Liver NDH1 transcript level of coastal smolts was higher than the level of K-wild (109\%; $\mathrm{p}=0.010)$ and hatchery smolts in May (118\%; $<$ 0.0001). Gill NDH1 transcript level increased from March to April in both wild $(116 \% ; p=0.003)$ and hatchery fish $(111 \% ; p=0.020)($ Fig. 11). K-wild fish showed higher gill NDH1 transcript levels (113\%) compared to hatchery fish in May (p < 0.0001). Gill NDH1 transcript levels of coastal smolts were higher (117\%; $\mathrm{p}<$ 0.0001 ) than the levels of hatchery smolts in May, while they were equal to the transcript level of K-wild fish in May.

\section{COX1 transcript level}

Liver COX1 transcript level of K-wild fish rose from March (3.56 $\pm 0.19 \mathrm{fmol}$ competitor/ $\mu$ g total RNA) to April (4.10 \pm 0.12 fmol competitor/ $\mu$ g total RNA; $\mathrm{p}=$ 
0.013), while there were no significant changes in the transcript level of hatchery fish during smoltification (Fig. 12). No difference was found in the transcript level between K-wild and hatchery fish in March and May. Coastal smolts (4.15 \pm 0.08 fmol competitor/ $\mu$ g total RNA) showed higher hepatic COX1 transcript levels compared to K-wild $(3.79 \pm 0.12 \mathrm{fmol}$ competitor/ $\mu$ g total RNA; $\mathrm{p}<0.0001)$ and hatchery fish in May (3.86 $\pm 0.14 \mathrm{fmol}$ competitor/ $\mu \mathrm{g}$ total RNA; $\mathrm{p}=0.014)$. Gill COX1 transcript level of K-wild fish increased from March (3.27 $\pm 0.44 \mathrm{fmol}$ competitor/ $\mu \mathrm{g}$ total RNA) to April (4.14 $\pm 0.16 \mathrm{fmol}$ competitor/ $\mu \mathrm{g}$ total RNA; $\mathrm{p}=$ 0.021), while the transcript level of hatchery fish decreased from April (3.85 \pm 0.12 fmol competitor/ $\mu \mathrm{g}$ total RNA) to May $(3.20 \pm 0.17 \mathrm{fmol}$ competitor/ $\mu \mathrm{g}$ total RNA; $\mathrm{p}=$ 0.006) (Fig. 12). K-wild fish showed higher gill COX1 transcript level compared to hatchery fish in May $(126 \% ; \mathrm{p}<0.0001)$. Gill COX1 transcript level of coastal smolts was higher $(140 \% ; \mathrm{p}<0.0001)$ than the level of hatchery smolts in May, whereas it was equal to the level of K-wild smolts in May.

\section{AST transcript level}

Liver AST transcript level increased from April (3.06 $\pm 0.29 \mathrm{fmol}$ competitor/ $\mu \mathrm{g}$ total RNA) to May (4.16 \pm 0.23 fmol competitor $\mu \mathrm{g}$ total RNA) in K-wild fish ( $\mathrm{p}=0.002)$, and from March (3.57 $\pm 0.31 \mathrm{fmol}$ competitor/ $\mu \mathrm{g}$ total RNA) to April (4.35 $\pm 0.17 \mathrm{fmol}$ competitor/ $\mu$ g total RNA) in hatchery fish $(\mathrm{p}=0.044)$ (Fig. 13). Liver AST transcript level of K-wild fish was higher $(136 \%)$ than hatchery fish in May $(\mathrm{p}<0.0001)$. Coastal smolts showed higher hepatic AST transcript level compared to K-wild (116\%; $\mathrm{p}=0.025)$ and hatchery smolts in May $(159 \% ; \mathrm{p}<0.0001)$. Increase in gill AST transcript level was found from March (3.32 $\pm 0.12 \mathrm{fmol}$ competitor/ $\mu \mathrm{g}$ total RNA) to May (3.93 \pm 0.13 fmol competitor/ $\mu$ g total RNA) in K-wild fish $(\mathrm{p}=0.004)$ and from March $(3.18 \pm 0.12 \mathrm{fmol}$ competitor $/ \mu \mathrm{g}$ total RNA) to April $(4.12 \pm 0.32 \mathrm{fmol}$ competitor/ $\mu$ g total RNA) in hatchery fish ( $\mathrm{p}=0.017)$ (Fig. 13). In May, gill AST transcript level of K-wild fish was higher $(130 \%)$ than the level of hatchery fish ( $\mathrm{p}<$ 0.0001). Coastal smolts showed higher gill AST transcript levels compared to K-wild $(\mathrm{p}<0.0001)$ and hatchery smolts in May $(\mathrm{p}<0.0001)$.

\section{Discussion}

In the present study, no differences in size (FL and BW) between $\mathrm{K}$-wild and hatchery fish from parr to mid-smolt stage were found, which suggested there were no effects of size difference on metabolic parameters. Declining CF, which has been accepted as a typical morphological change during smoltification (McCormick and 
Saunders, 1987), was detected from April to May in only K-wild fish. Absence of declined $\mathrm{CF}$ in hatchery fish may result from environment peculiar to hatchery-culture. Increased gill $\mathrm{Na}^{+}, \mathrm{K}^{+}$-ATPase activity, which showed development of seawater adaptability during smoltification, was observed in both K-wild and hatchery fish, and there was no difference in the activity between K-wild and hatchery fish. These data suggest that there were no differences in seawater adaptability between K-wild and hatchery fish in our study. Similar results were previously reported in Mizuno et al. (2004). Higher gill $\mathrm{Na}^{+}, \mathrm{K}^{+}$-ATPase activity in coastal smolts compared to freshwater-adapted K-wild and hatchery mid-smolts suggests more development of seawater adaptability by entry to seawater, which was earlier reported (McCormick et al. 1989a). These differences between coastal smolt and freshwater-adapted smolts are unaffected by changes in temperature and developmental smolt stage, since there were almost no differences in water temperature between the Ken-ichi River $\left(9.8^{\circ} \mathrm{C}\right)$ and the Nemuro Bay $\left(9.7^{\circ} \mathrm{C}\right)$ at sampling time and distinction in smolt stage between mid-smolt and post-smolt depends on only difference in habitat between freshwater and seawater in masu salmon (Kubo 1980).

\section{Metabolic changes during smoltification under natural conditions}

It is well-known that carbohydrate and lipid metabolism are enhanced during smoltification and the transfer from freshwater to seawater in anadromous salmonids (reviewed in Høgåsen 1999). The present study found reduction in hepatic GC and TG content from the parr to pre-smolt stage in K-wild fish, which suggests activation of glycogenolysis and lipolysis during smoltification. Decreases in hepatic GC and TG content was earlier reported in Atlantic salmon (Wendt and Saunders, 1973), coho salmon (Sheridan et al. 1985; Sheridan 1986) and chinook salmon (Cowley et al. 1994); glycogenolysis and lipolysis of masu salmon during smoltification resembles these changes in other salmon. On the other hand, there has been no consensus on the drop in serum GL concentration during smoltification which was found in our study. Ji et al. (1996) found reduction in blood GL level with decreased hepatic GC in Atlantic salmon smolts, whereas Aas-Hansen et al. (2005) discovered increases in plasma GL with decreased hepatic GC during smoltification in Arctic char (Salvelinus alpinus). The discrepancy in these two earlier studies may be caused by differences in analysis method between serum and plasma. On the other hand, this discrepancy is perhaps due to hepatic activity of lactate-dependent gluconeogenesis during smoltification for the cause that reduced capacity for gluconeogenesis from lactate contributes to depressed blood GL and liver GC during smoltification in Atlantic salmon (Ji et al., 
1996), if there are no impacts of differences in the blood analysis method. If the latter cause is correct, our data suggest that carbohydrate metabolism during smoltification in masu salmon is more similar to that of Atlantic salmon rather than Arctic char. In our study, depressed liver LDH activity from the parr to pre-smolt stage in K-wild fish may support reduction of lactate-dependent gluconeogenesis. Coastal smolts revealed lower hepatic GC content compared to freshwater-adapted mid-smolts. Reduced hepatic GC content transferred to seawater has been observed in rainbow trout (Soengas et al., 1995a), coho salmon and chinook salmon (Sheridan, 1988); these studies support our result and reflect greater activation of hepatic glycogenolysis in seawater compared to freshwater. In K-wild fish, ATP content reduced in the liver from March to April, while it showed a little increase during smoltification in the gill. This difference between liver and gill may be generated by differences in gluconeogenesis, which runs using ATP, because liver is the primary organ for gluconeogenesis, while gill functions less on gluconeogenesis. Our study found that PRK activity was enhanced during smoltification in the liver and gill of K-wild fish, which suggests glycolysis activation during smoltification. This change presumably results from reduced hepatic ATP content and increased gill ATP demand by enhanced $\mathrm{Na}^{+}, \mathrm{K}^{+}$-ATPase activity, since ATP is accepted as an allosteric effecter to glycolytic enzymes (Walton and Cowey, 1982). Another notable point on PRK activity of K-wild fish was that increased hepatic activity preceded gill activity increases in time. The time lag may reflect differences in osmoregulatory ability between gill and liver. Gill functions as the main osmoregulatory organ, whereas liver is less related to osmoregulation. Gill $\mathrm{Na}^{+}$, $\mathrm{K}^{+}$-ATPase activity of $\mathrm{K}$-wild fish reached maximal levels at mid-smolt stage, which may reveal that increased gill PRK activity contributes to compensation of increased ATP consumption by enhanced gill $\mathrm{Na}^{+}, \mathrm{K}^{+}$-ATPase activity. Furthermore, coastal smolts demonstrated more accelerated hepatic glycolysis in seawater than freshwater smolts and maintained gill glycolysis at high level in seawater. Increases in liver and gill HOAD activity during smoltification was not found in K-wild fish, although liver TG content decreased during smoltification. These results demonstrate that $\beta$-oxidation of fatty acid does not activate regardless of high TG decomposition, which may suggest that smolting masu salmon do not use lipid as the main energy source in freshwater. However, hepatic HOAD activity generally increases during smoltification in other salmonids. Therefore, no change in HOAD activity during smoltification may be specific to masu salmon. Another remarkable point on HOAD activity was that coastal smolts showed higher liver and gill HOAD activities compared to freshwater-adapted smolts, which suggests that lipolysis activates more in seawater than 
in freshwater. Increased CRK activity during smoltification was found in the liver and gill of K-wild fish, which suggests activation of creatine phosphate resolution during smoltification. Changes in hepatic and gill CRK activity during smoltification have not been previously reported, although the presence of CRK was elucidated in the liver, white and red muscles, kidney, heart and brain of rainbow trout (Ito, 1986). Therefore, the present study is the first report which showed increases in hepatic and gill CRK activity during smoltification. Resolution of creatine phosphate is a means to acquire ATP faster than anaerobic glycolysis or the respiratory chain. Predictable rapid activation of some glycolysis and lipolysis-related enzymes, 6-phosphofructo 1-kinase, phosphoglycerate kinase and acyl-CoA synthetase, during smoltification abruptly demands ATP, which may suggest that increased CRK activity contributes to rapid activation of glycolysis and lipolysis during smoltification. Our study found higher CRK activity in coastal smolts compared to freshwater smolts, which suggest that the ability for ATP production by resolution of creatine phosphate develops more in seawater than in freshwater. The differences between coastal smolts and freshwater-adapted smolts are unaffected by changes in temperature and developmental smolt stage for above-mentioned reasons. It is generally accepted that marine environmental conditions such as food, salinity and other water quality parameters is highly variable in coastal regions. This consideration reveals that coastal smolts need to acquire ATP rapidly by resolution of creatine phosphate to adapt to the stress of rapid marine environmental changes. Reduction in hepatic LDH activities during smoltification of K-wild fish and lower liver and gill LDH activity in coastal smolts compared to K-wild mid-smolts were found in our study, which suggest more weakened anaerobic glycolysis during smoltification and in seawater. Plisetskaya et al. (1994) demonstrated that reduced hepatic LDH activity during smoltification, which agreed with our result, was maintained for 3 months after seawater transfer in coho salmon and Atlantic salmon. Soengas et al. (1995a) revealed unchangeable hepatic LDH activity of small rainbow trout, but increased hepatic LDH activity of large rainbow trout during seawater transfer. These earlier studies reveal that changes in LDH activity during smoltification and seawater transfer depend on difference in species and/or body size. Another important finding was increased liver and gill CS and COX activity during smoltification, which reflects activation of the citric acid cycle and respiratory chain during smoltification. K-wild smolting masu salmon may direct respiration means toward aerobic type at mid-smolt stage, since citric acid cycle and respiratory chain activates under only aerobic environments. Enhanced hepatic and gill CS activity during smoltification was sustained by McCormick et al. (1989b) and Leonard and 
McCormick (2001). However, McCormick et al. (1989b) reported no changes in hepatic and gill COX activity during smoltification, while smolts showed higher COX activity compared to non-smolt. The disagreement in COX activity between this earlier result and our result may stem from variation of experimental conditions such as differences in species and differences between hatchery and wild fish. Coastal smolts showed high levels of liver and gill CS and COX activities, which was not different from the levels of freshwater-adapted smolts. These results reflect that the high activity of the citric acid cycle and respiratory chain is maintained in the seawater-adapted smolt. McCormick et al. (1989a) found no effects of seawater exposure on gill CS in Atlantic salmon smolt, which supported our result. Transcript levels of hepatic and gill NDH1, COX1 and AST increased during smoltification, which may be because the amount of respiratory chain enzymes increases to complement activation of the respiratory chain during smoltification. Two notable points in both liver and gill were that increased of the time of increased COX1 transcript levels preceded that of COX activity and that increases in AST transcript level followed increases in the level of NDH1 and COX1. The former time lag may reveal time differences from transcription to activation through COX translation, which was revealed in Moyes et al. (1997). The latter time lag is perhaps concerned with order of action in respiratory chain enzymes, since $\mathrm{NDH}, \mathrm{COX}$ and AST operate respiratory chain in sequence. Coastal smolts demonstrated high transcript levels of the respiratory chain enzymes, which was equivalent or higher than the level of freshwater-adapted mid-smolts. These results may reflect that masu salmon need high levels of respiratory chain enzymes to adapt to the stress of the changeable coastal environment.

\section{Differences in metabolic parameters between wild and hatchery fish}

Decreases in hepatic GC content and serum GL concentration during smoltification, which was shown in K-wild fish, was not found in hatchery fish. At the parr stage, hepatic GC content of hatchery fish was less than the content of K-wild fish. These findings suggest low glycogenolysis during smoltification and low use rate of glycogen as an energy source in hatchery fish. It is possible that hatchery fish depend on gluconeogenesis and protein as an energy source, because there was no difference in liver TG content between hatchery and K-wild fish. Hatchery fish demonstrated positive changes in hepatic ATP content during smoltification, whereas K-wild fish presented negative changes in the concentration during smoltification. At the mid-smolt stage, hatchery fish showed higher hepatic ATP content compared to K-wild 
fish and coastal smolts. In the gill, hatchery fish revealed no changes in ATP content during smoltification, while K-wild fish showed temporary increases in the content during smoltification. These results suggest that hatchery fish show low activity and expression levels of some hepatic and gill metabolic enzymes during smoltification and in seawater, because activation and gene expression of some enzymes related to glycolysis, lipolysis, citric acid cycle and the respiratory chain are controlled by ATP content. Reduction in hepatic PRK activity was observed during the mid-smolt stage in hatchery fish, while there was no decrease in activity at the same stage in K-wild fish. An increase in gill PRK activity during smoltification, which was revealed in K-wild fish, was not found in hatchery fish. These findings suggest low glycolytic changes during smoltification and low use rate of glycolysis at mid-smolt stage in hatchery fish. Another notable point on hepatic PRK activity was that hatchery smolts showed lower activity than K-wild mid-smolts and coastal smolt, which reflects that glycolysis of hatchery smolt does not adjust seawater-type glycolysis. Our study discovered differences timing of increases of hepatic CS activity between hatchery fish and K-wild fish and the absence of increased gill CS activity during smoltification in hatchery fish, which reveals that hatchery fish show low level of citric acid cycle changes during smoltification. Hatchery smolts showed lower liver and gill CS activity compared to K-wild smolts at mid-smolt stage and to coastal smolts, which suggests that liver and gill of hatchery smolts cannot adapt their citric acid cycle to a seawater-type. Drastic increases and decreases in hepatic LDH activity during smoltification were found in hatchery fish, while only reduction in the activity during smoltification was revealed in K-wild fish. Our results suggest low level of anaerobic glycolysis during smoltification in hatchery fish. Lower liver COX activity in hatchery smolt compared to K-wild smolts at mid-smolt stage and to coastal smolts possibly represents that hatchery smolt cannot prepare for a seawater-type hepatic respiratory chain. There were differences in changes in transcript level of almost all of the hepatic and gill respiratory chain enzymes during smoltification between hatchery and $\mathrm{K}$-wild fish. Differences in timing of liver and gill AST transcript level increases between hatchery and wild fish were found in the present study. Hatchery smolt demonstrated lower transcript levels of some hepatic and gill respiratory chain enzymes at the mid-smolt stage compared to K-wild smolts and coastal smolts. These findings reflect that hatchery fish cannot prepare much respiratory chain enzyme before seaward migration. On the other hand, there was no conspicuous difference in hepatic and gill HOAD and CRK activity between hatchery and K-wild fish, which suggest that hatchery fish can practice same changes in lipolysis and resolution of creatine phosphate during 
smoltification as wild fish.

Our study found that hatchery masu salmon had some problems in carbohydrate metabolism, the citric acid cycle, and the respiratory chain, which suggests that hatchery fish may not adjust to marine life after migrating from the river to sea leading to mortality. Walton (1986) reported that low carbohydrate and high protein food intake affected low activities of glycolytic enzymes and citric acid cycle in rainbow trout. Moreover, Brauge et al. (1994) revealed that elevated digestible carbohydrate intake resulted in glycaemia in rainbow trout. These papers possibly suggest that the problem with our hatchery fish is caused by low carbohydrate in the diet. Meanwhile, Leonard and McCormick (2001) found that there were significant differences in fluctuation or increased time of some metabolic enzyme activity during smoltification between hatchery and wild fish in the liver, heart and white muscle in Atlantic salmon, which indicated metabolic problems on hatchery fish. McCormick and Björnsson (1994) found higher levels of plasma cortisol, which is a stress-related hormone and involved in stimulating or maintaining increased plasma GC and gluconeogenesis, in hatchery smolt than migrating stream-reared smolts, which may reflect that hatchery fish experience greater stress than wild fish. This consideration may demonstrate that metabolic problems in hatchery fish result from the stress of the artificial rearing environment such as feeding, artificial handling and high rearing density. In addition, Misaka et al. (2004) have found that fasting induced rapid decreases in hepatic GC content of masu salmon, which suggest that amount of supplied food impacts on hepatic GC content. Therefore, small hepatic GC content of hatchery fish found in our study is possibly caused by stress related to less food. Acute handling stress, which often occurs at fish transportation in hatchery fish, induces temporary increase in plasma cortisol and GL level (Carey and McCormick, 1998). These earlier results suggest considerable increased plasma cortisol level related to handling stress disturbs carbohydrate metabolism in hatchery fish of our study. High rearing density resulted in reduced plasma levels of some hormones related to smoltification in smolting coho salmon (Patino et al., 1986) and in increased plasma GL levels and low growth rate in rainbow trout (Procarione et al., 1999). Carbohydrate metabolism is directly or indirectly regulated by not only cortisol but also insulin, glucagon and epinephrine in fish. Therefore, this consideration may reveal that predictable social stress related to high rearing density disturbs endocrine control of carbohydrate metabolism in our hatchery fish. It is the best way to improve dietary quality and/or remove artificial culture-dependent stresses in order to solve metabolic problem with hatchery masu salmon. 
In conclusion, the present study elucidated that glycolysis, lipolysis, creatine phosphate resolution, the citric acid cycle and the respiratory chain are activated and anaerobic respiration declines during smoltification under natural conditions in masu salmon. Our study pointed out that hatchery fish used in the present study held some physiological problems on carbohydrate metabolism, citric acid cycle and respiratory chain during smoltification. Our presented data will contribute to producing released hatchery juvenile with high quality for stock enhancement of masu salmon.

\section{Acknowledgements}

We would like to thank Dr Munetaka Shimizu and Dr Hideaki Kudo, Faculty of Fisheries Science, Hokkaido University for their valuable comments throughout this study and Dr Jill B. K. Leonard, Biology Department, Northern Michigan University for her critical reading of this manuscript. This study was supported by grant-in-aid from the Department of Fisheries and Forestry, Hokkaido Government.

\section{References}

Aas-Hansen, Ø., Vijayan, M.M., Johnsen, H.K., Cameron, C., Jørgensen, E.H., 2005. Resmoltification in wild, anadromous Arctic char (Salvelinus alpines): a survey of osmoregulatory, metabolic, and endocrine changes preceding annual seawater migration. Can. J. Fish. Aquat. Sci. 62, 195-204.

Brauge, C., Medale, F., Corraze, G., 1994. Effect of dietary carbohydrate levels on growth. body composition and glycaemia in rainbow trout, Oncorhynchus mykiss, reared in seawater. Aquaculture 123, 109-120.

Burness, G., Moyes, C.D., Montgomerie, R., 2005. Mortility, ATP levels and metabolic enzyme activity of sperm from bluegill (Lepomis macrochirus). Comp. Biochem. Physiol. A140, 11-17.

Carey, J.B., McCormick, S.D., 1998. Atlantic salmon smolts are more responsive to an acute handling and confinement stress than parr. Aquaculture 168, 237-253.

Cowley, D.J., Sheridan, M.A., Hoffnagle, T.L., Fivizzani, A.J., Barton, B.A., Eilertson, C.D., 1994. Changes in lipid metabolism and plasma concentrations of thyroxine, cortisol, and somatostatin in land-locked chinook salmon, Oncorhynchus tshawytscha, during smoltification. Aquaculture 121, 147-155. 
Høgåsen, H.R., 1998. Physiological changes associated with the diadromous migration of salmonids. NRC Research Press, Montreal.

Ito, Y., 1986. Studies on creatine kinase of fishes. Bull. Fac. Agr. Tokai Univ. 5, 123-129.

Ji, H., Bradley, T.M., Tremblay, G.C., 1996. Lactate-dependent gluconeogenesis and atractyloside-sensitive flux through pyruvate carboxylase are reduced during smoltification of Atlantic salmon (Salmo salar). J. Exp. Zool. 276, 375-386.

Kato, F., 1991. Life histories of masu and amago salmon (Oncorhynchus masou and Oncorhynchus rhodurus), in: Groot, C., Margolis, L. (Eds.), Pacific salmon life histories. UBC Press, Vancouver, pp. 447-520.

Kubo, T., 1980. Studies on the life history of the masu salmon (Oncorhynchus masou) in Hokkaido. Sci.Rep. Hokkaido Salmon Hatchery 34, 1-95.

Langdon, J.S., Thorpe, J.E., 1985. The ontogeny of smoltification: developmental patterns of gill $\mathrm{Na}^{+}, \mathrm{K}^{+}$-ATPase, $\mathrm{SDH}$ and chloride cells in juvenile Atlantic salmon, Salmo salar L. Aquaculture 45, 83-96.

Leonard, J.B.K., McCormick, S.D., 2001. Metabolic enzyme activity during smolting in stream- and hatchery-reared Atlantic salmon (Salmo salar). Can. J. Fish. Aquat. Sci. 58, 1585-1593.

Maxime, V., Boeuf, G., Pennec, J.P., Peyraud, C., 1989. Comparative study of the energetic metabolism of Atlantic salmon (Salmo salar) parr and smolts. Aquaculture 82, 163-171.

McCormick, S.D., Björnsson, B.T., 1994. Physiological and hormonal differences among Atlantic salmon parr and smolts reared in the wild and hatchery smolts. Aquaculture 121, 235-244.

McCormick, S.D., Saunders, R.L., 1987. Preparatory physiological adaptations for marine life of salmonids: osmoregulation, growth, and metabolism. Am. Fish. Soc. 
Symp. 1, 211-229.

McCormick, S.D., Moyes, C.D., Ballantyne, J.S., 1989a. Influence of salinity on the energetics of gill and kidney of Atlantic salmon (Salmo salar). Fish Physiol. Biochem. 6, 243-254.

McCormick, S.D., Saunders, R.L., MacIntyre, A.D., 1989b. Mitochondrial enzyme and $\mathrm{Na}^{+}, \mathrm{K}^{+}$-ATPase activity, and ion regulation during parr-smolt transformation of Atlantic salmon (Salmo salar). Fish. Physiol. Biochem. 6, 231-241.

Misaka, N., Mizuno, S., Miyakoshi, Y., Takeuchi, K., Takami, T., Kasahara, N., 2004. Changes of triglyceride and glycogen levels in the liver of underyearling masu salmon Oncorhynchus masou during starvation. Nippon Suisan Gakkaishi 70, 168-174.

Mizuno, S., Misaka, N., Ando, D., Kitamura, T., 2004. Quantitative changes of black pigmentation in the dorsal fin margin during smoltification in masu salmon, Oncorhynchus masou. Aquaculture 229, 433-450.

Mizuno, S., Misaka, N., Teranishi, T., Ando, D., Koyama, T., Araya, K., Miyamoto, M., Nagata, M., 2008. Physiological effects of an iron citrate dietary supplement on chum salmon (Oncorhynchus keta) fry. Aquaculture Sci. 56, 531-542.

Moyes, C.D., Mathieu-Costello, O.A., Tsuchiya, N., Filburn, C., Hansford, R.G., 1997. Mitochondrial biogenesis during cellular differentiation. Am. J. Physiol. 272, C1345-1351.

Patino, R., Schreck, C.B., Banks, J.L., Zaugg, W.S., 1986. Effects of rearing conditions on the developmental physiology of smolting coho salmon. Trans. Am. Fish. Soc. 115, 828-837.

Plisetskaya, E.M., Moon, T.W., Larsen, D.A., Foster, G.D., Dickhoff, W.W., 1994. Liver glycogen, enzyme activities, and pancreatic hormones in juvenile Atlantic salmon (Salmo salar) during their first summer in seawater. Can. J. Fish. Aquat. Sci. 51, 567-576.

Procarione, L.S., Barry, T.P., Malison, J.A., 1999. Effects of high rearing densities and 
loading rates on the growth and stress responses of juvenile rainbow trout. North Am. J. Aquacult. 61, 91-96.

Riley, W.D., Ibbotson, A.T., Lower, N., Cook, A.C., Moore, A., Mizuno, S., Pinder, A.C., Beaumont, W.R.C., Privitera, L., 2008. Physiological seawater adaptation in juvenile Atlantic salmon (Salmo salar) autumn migrants. Freshwater Biol. 53, 745-755.

Saunders, R.L., Henderson, E.B., 1978. Changes in gill ATPase activity and smolt status of Atlantic salmon (Salmo salar). J. Fish. Res. Board Canada 35, 1542-1546.

Sheridan, M.A., 1986. Effects of thyroxine, cortisol, growth hormone, and prolactin on lipid metabolism of coho salmon, Oncorhynchus kisutch, during smoltification. Gen. Comp. Endocrinol. 64, 220-238.

Sheridan, M.A., 1988. Exposure to seawater stimulates lipid mobilization from depot tissues of juvenile coho (Oncorhynchus kisutch) and Chinook (O. tshawytscha) salmon. Fish Physiol. Biochem. 5, 173-180.

Sheridan, M.A., Woo, N.Y., Bern, H.A., 1985. Changes in the rates of glycogenesis, glycogenolysis, lipogenesis, and lipolysis in selected tissues of the coho salmon (Oncorhynchus kisutch) associated with parr-smolt transformation. J. Exp. Zool. 236, $35-44$.

Soengas, J.L., Aldegunde, M., Andrés, D. 1995a. Gradual transfer to sea water of rainbow trout: effects on liver carbohydrate metabolism. J. Fish. Biol. 47, 466-478.

Soengas, J.L., Barciela, P., Aldegunde, M., Andrés, D. 1995b. Gill carbohydrate metabolism of rainbow trout is modified during gradual adaptation to sea water. J. Fish. Biol. 46, 845-856.

Soengas, J.L., Fuentes, J., Andrés, D., Aldegunde, M., 1995c. The effect of gradual transfer to sea water on muscle carbohydrate metabolism of rainbow trout. J. Fish. Biol. 46, 509-523.

Walton, M.J., 1986. Metabolic effects of feeding a high protein/low carbohydrate diet as compared to a low protein/high carbohydrate diet to rainbow trout Salmo gairdneri. Fish 
Physiol. Biochem. 1, 7-15.

Walton, M.J., Cowey, C.B., 1982. Aspect of intermediary metabolism in salmonid fish. Comp. Biochem. Physiol. 73B, 59-79.

Wendt, C.A.G., Saunders, R.L., 1973. Changes in carbohydrate metabolism in young Atlantic salmon in response to various forms of stress. Int. Atl. Salmon Found. Spec. Publ. Ser. 4, 55-82.

Zardoya, R., Garrido-Pertierra, A., Bautista, J.M., 1995. The complete nucleotide sequence of the mitochondrial DNA genome of the rainbow trout, Oncorhynchus mykiss. J. Mol. Evol. 41, 942-951. 


\section{Figure legends}

Fig.1

Gill $\mathrm{Na}^{+}, \mathrm{K}^{+}$-ATPase activities of masu salmon used in the present study. The data were shown as the means \pm standard errors. Sample numbers in each data were 10,10 and 7 in K-wild fish, hatchery fish and coastal smolt, respectively. Different small alphabetical letters indicated differences $(p<0.05)$ in the value between K-wild and hatchery fish on March and April and among K-wild fish, hatchery fish and coastal smolt on May plus June. Asterisks revealed differences ( $p<0.05)$ compared to the value of the same parameter on March in the same group. The value with cross mark was different from the value a month before in the same group $(\mathrm{p}<0.05)$.

Fig. 2

Serum glucose (GL) concentrations and liver glycogen (GC) contents of masu salmon used in the present study. The data were shown as the means \pm standard errors. Sample numbers in each data were 10, 10 and 7 in K-wild fish, hatchery fish and coastal smolt, respectively. Different small alphabetical letters indicated differences $(\mathrm{p}<0.05)$ in the value between K-wild and hatchery fish on March and April and among K-wild fish, hatchery fish and coastal smolt on May plus June. Asterisks revealed differences $(p<0.05)$ compared to the value of the same parameter on March in the same group. The value with cross mark was different from the value of the same parameter a month before in the same group $(\mathrm{p}<0.05)$.

Fig. 3

Liver triglyceride (TG) contents of masu salmon used in the present study. The data were shown as the means \pm standard errors. Sample numbers in each data were 10, 10 and 7 in K-wild fish, hatchery fish and coastal smolt, respectively. Different small alphabetical letters indicated differences $(\mathrm{p}<0.05)$ in the value between $\mathrm{K}$-wild and hatchery fish on March and April and among K-wild fish, hatchery fish and coastal smolt on May plus June. The value with cross mark was different from the value a month before in the same group $(\mathrm{p}<0.05)$.

Fig.4

Liver and gill ATP contents of masu salmon used in the present study. The data were shown as the means \pm standard errors. Sample numbers in each data were 10, 10 and 7 in K-wild fish, hatchery fish and coastal smolt, respectively. Different small alphabetical letters indicated differences $(\mathrm{p}<0.05)$ in the value between $\mathrm{K}$-wild and 
hatchery fish on March and April and among K-wild fish, hatchery fish and coastal smolt on May plus June. Asterisks revealed differences $(p<0.05)$ compared to the value of the same parameter on March in the same group. The value with cross mark was different from the value of the same parameter a month before in the same group $(\mathrm{p}$ $<0.05)$.

Fig. 5

Liver and gill pyruvate kinase (PRK) activities of masu salmon used in the present study. The data were shown as the means \pm standard errors. Sample numbers in each data were 10, 10 and 7 in K-wild fish, hatchery fish and coastal smolt, respectively.

Different small alphabetical letters indicated differences $(\mathrm{p}<0.05)$ in the value between K-wild and hatchery fish on March and April and among K-wild fish, hatchery fish and coastal smolt on May plus June. Asterisks revealed differences ( $\mathrm{p}<0.05$ ) compared to the value of the same parameter on March in the same group. The value with cross mark was different from the value of the same parameter a month before in the same group $(\mathrm{p}<0.05)$.

Fig.6

Liver and gill 3-hydroxyacyl-CoA dehydrogenase (HOAD) activities of masu salmon used in the present study. The data were shown as the means \pm standard errors.

Sample numbers in each data were 10, 10 and 7 in K-wild fish, hatchery fish and coastal smolt, respectively. Different small alphabetical letters indicated differences $(\mathrm{p}<0.05)$ in the value between K-wild and hatchery fish on March and April and among K-wild fish, hatchery fish and coastal smolt on May plus June.

Fig.7

Liver and gill creatine phosphokinase (CRK) activities of masu salmon used in the present study. The data were shown as the means \pm standard errors. Sample numbers in each data were 10, 10 and 7 in K-wild fish, hatchery fish and coastal smolt, respectively. Different small alphabetical letters indicated differences $(p<0.05)$ in the value between K-wild and hatchery fish on March and April and among K-wild fish, hatchery fish and coastal smolt on May plus June. Asterisks revealed differences ( $\mathrm{p}$ 0.05) compared to the value of the same parameter on March in the same group. The value with cross mark was different from the value of the same parameter a month before in the same group $(\mathrm{p}<0.05)$. 
Fig. 8

Liver and gill citrate synthase (CS) activities of masu salmon used in the present study. The data were shown as the means \pm standard errors. Sample numbers in each data were 10, 10 and 7 in K-wild fish, hatchery fish and coastal smolt, respectively.

Different small alphabetical letters indicated differences $(\mathrm{p}<0.05)$ in the value between $\mathrm{K}$-wild and hatchery fish on March and April and among K-wild fish, hatchery fish and coastal smolt on May plus June. Asterisks revealed differences ( $p<0.05)$ compared to the value of the same parameter on March in the same group. The value with cross mark was different from the value of the same parameter a month before in the same group $(\mathrm{p}<0.05)$.

Fig. 9

Liver and gill lactate dehydrogenase (LDH) activities of masu salmon used in the present study. The data were shown as the means \pm standard errors. Sample numbers in each data were 10, 10 and 7 in K-wild fish, hatchery fish and coastal smolt, respectively. Different small alphabetical letters indicated differences $(p<0.05)$ in the value between K-wild and hatchery fish on March and April and among K-wild fish, hatchery fish and coastal smolt on May plus June. Asterisk revealed difference $(\mathrm{p}<$ 0.05) compared to the value of the same parameter on March in the same group. The value with cross mark was different from the value of the same parameter a month before in the same group $(\mathrm{p}<0.05)$.

Fig. 10

Liver and gill cytochrome $c$ oxidase (COX) activities of masu salmon used in the present study. The data were shown as the means \pm standard errors. Sample numbers in each data were 10, 10 and 7 in K-wild fish, hatchery fish and coastal smolt, respectively. Different small alphabetical letters indicated differences $(p<0.05)$ in the value between K-wild and hatchery fish on March and April and among K-wild fish, hatchery fish and coastal smolt on May plus June. Asterisks revealed differences ( $p<$ 0.05) compared to the value of the same parameter on March in the same group. The value with cross mark was different from the value of the same parameter a month before in the same group $(\mathrm{p}<0.05)$.

Fig.11

Transcript levels of liver and gill NADH dehydrogenase subunit 1 (NDH1) in masu salmon used in the present study. The data were shown as the means \pm standard errors. 
Sample numbers in each data were 10, 10 and 7 in K-wild fish, hatchery fish and coastal smolt, respectively. Different small alphabetical letters indicated differences $(\mathrm{p}<0.05)$ in the value between K-wild and hatchery fish on March and April and among K-wild fish, hatchery fish and coastal smolt on May plus June. Asterisks revealed differences $(p<0.05)$ compared to the value of the same parameter on March in the same group. The value with cross mark was different from the value of the same parameter a month before in the same group $(\mathrm{p}<0.05)$.

Fig.12

Transcript levels of liver and gill cytochrome $c$ oxidase subunit 1 (COX1) in masu salmon used in the present study. The data were shown as the means \pm standard errors. Sample numbers in each data were 10, 10 and 7 in K-wild fish, hatchery fish and coastal smolt, respectively. Different small alphabetical letters indicated differences $(p<0.05)$ in the value between K-wild and hatchery fish on March and April and among K-wild fish, hatchery fish and coastal smolt on May plus June. Asterisk revealed difference ( $p$ $<0.05$ ) compared to the value of the same parameter on March in the same group. The value with cross mark was different from the value of the same parameter a month before in the same group $(\mathrm{p}<0.05)$.

Fig.13

Transcript levels of liver and gill ATP synthase subunit 8 (AST) in masu salmon used in the present study. The data were shown as the means \pm standard errors. Sample numbers in each data were 10, 10 and 7 in K-wild fish, hatchery fish and coastal smolt, respectively. Different small alphabetical letters indicated differences $(p<0.05)$ in the value between K-wild and hatchery fish on March and April and among K-wild fish, hatchery fish and coastal smolt on May plus June. Asterisk revealed difference $(\mathrm{p}<$ 0.05 ) compared to the value of the same parameter on March in the same group. The value with cross mark was different from the value of the same parameter a month before in the same group $(\mathrm{p}<0.05)$. 


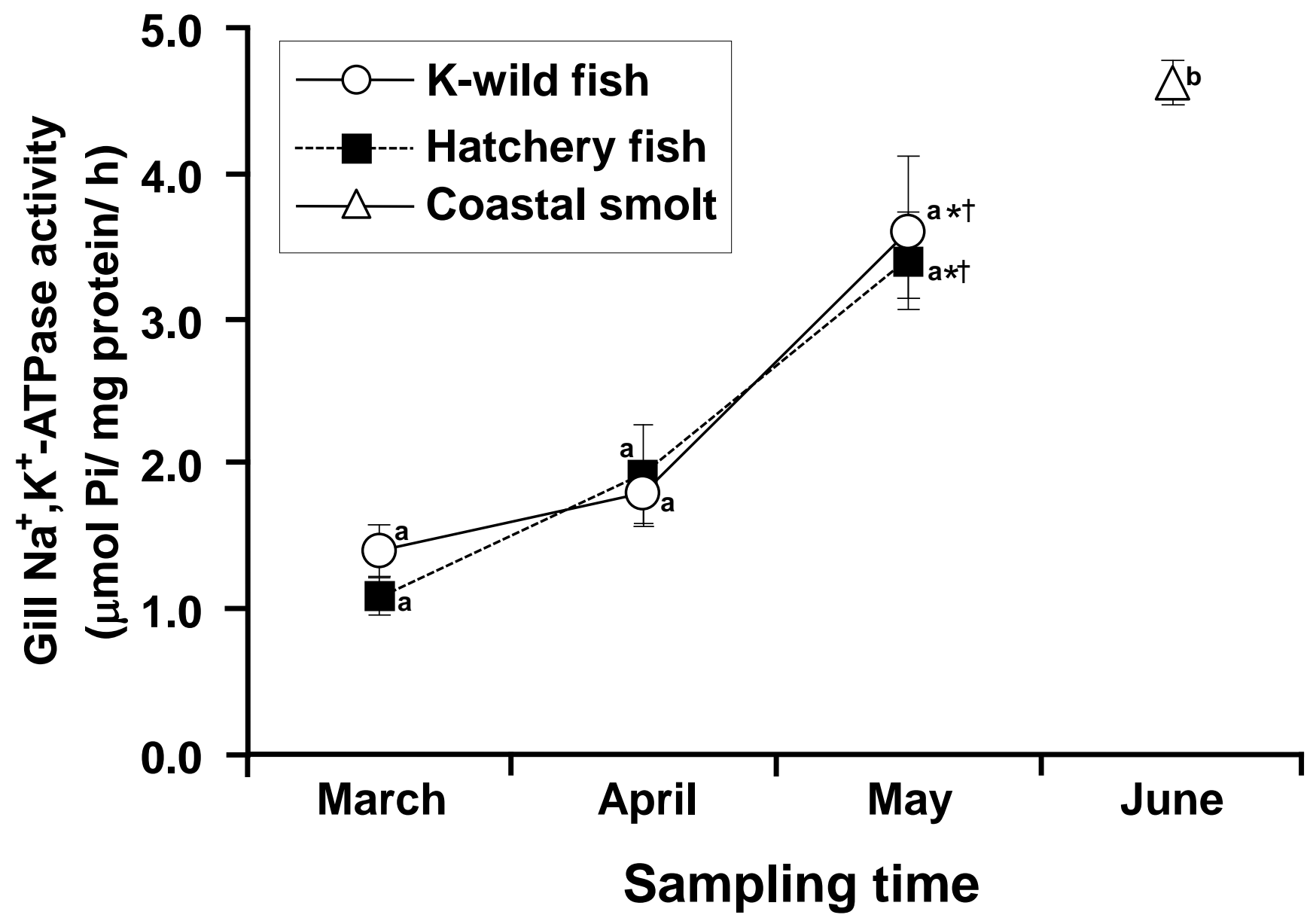

Fig.1 

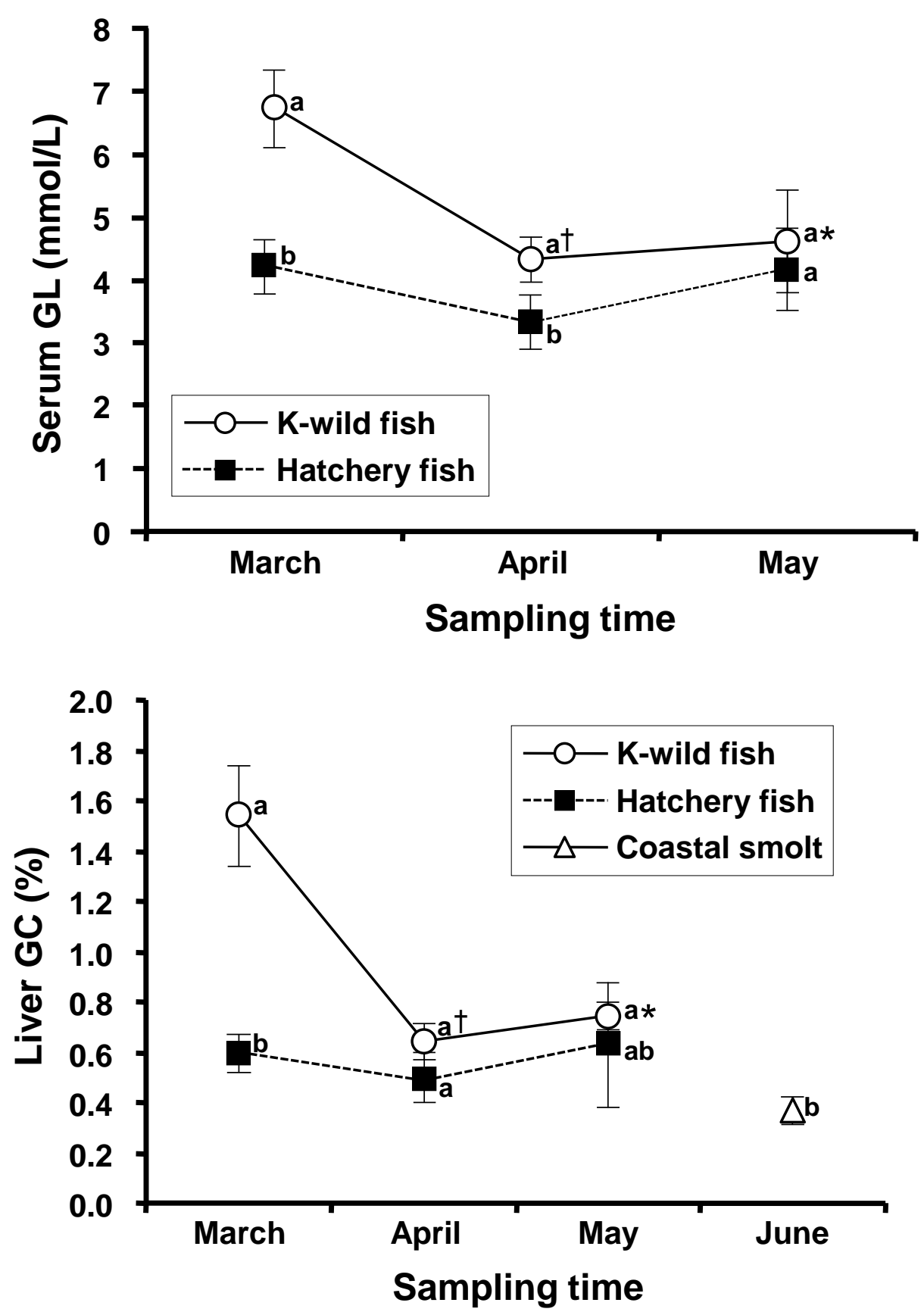

Fig.2 


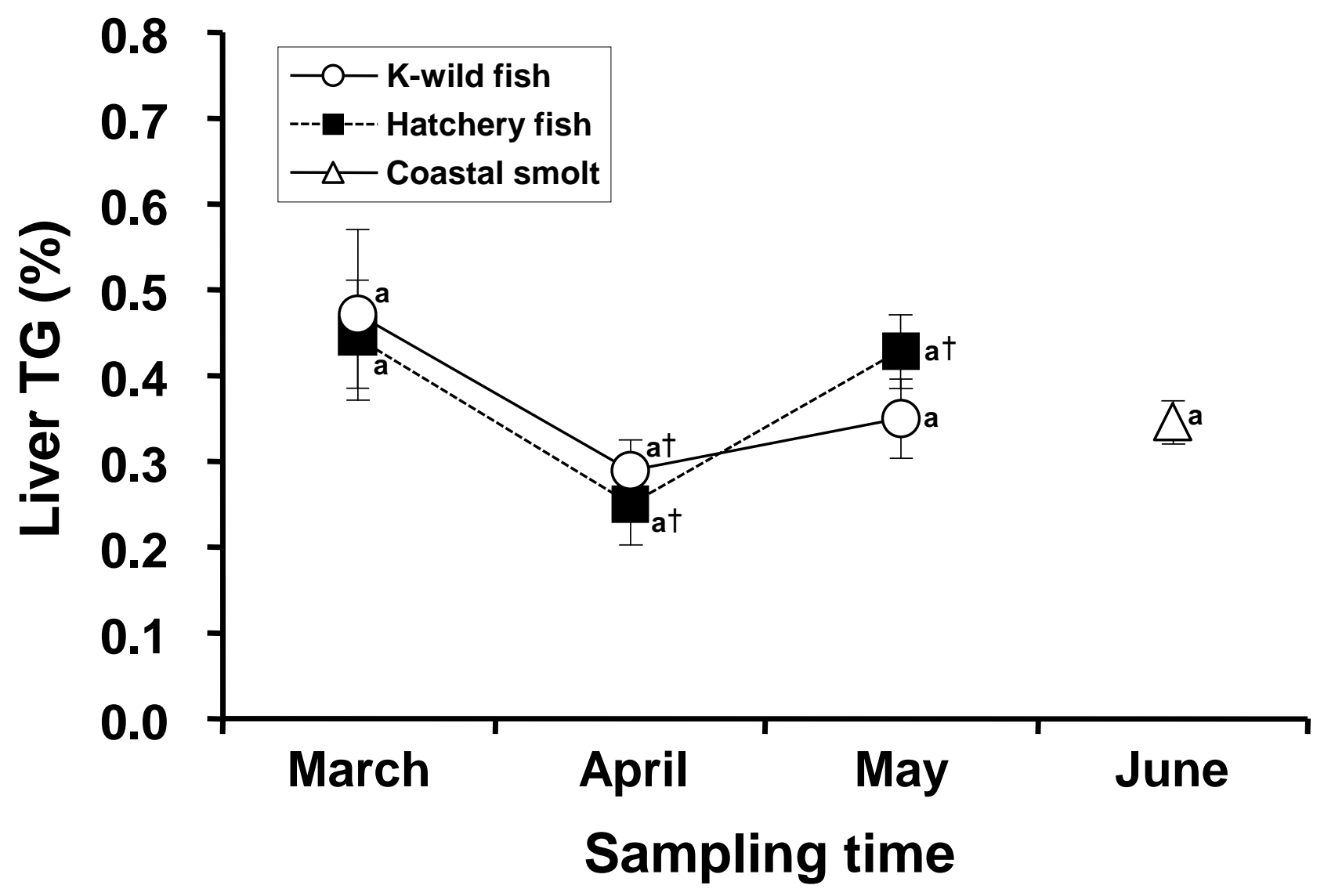

Fig.3 

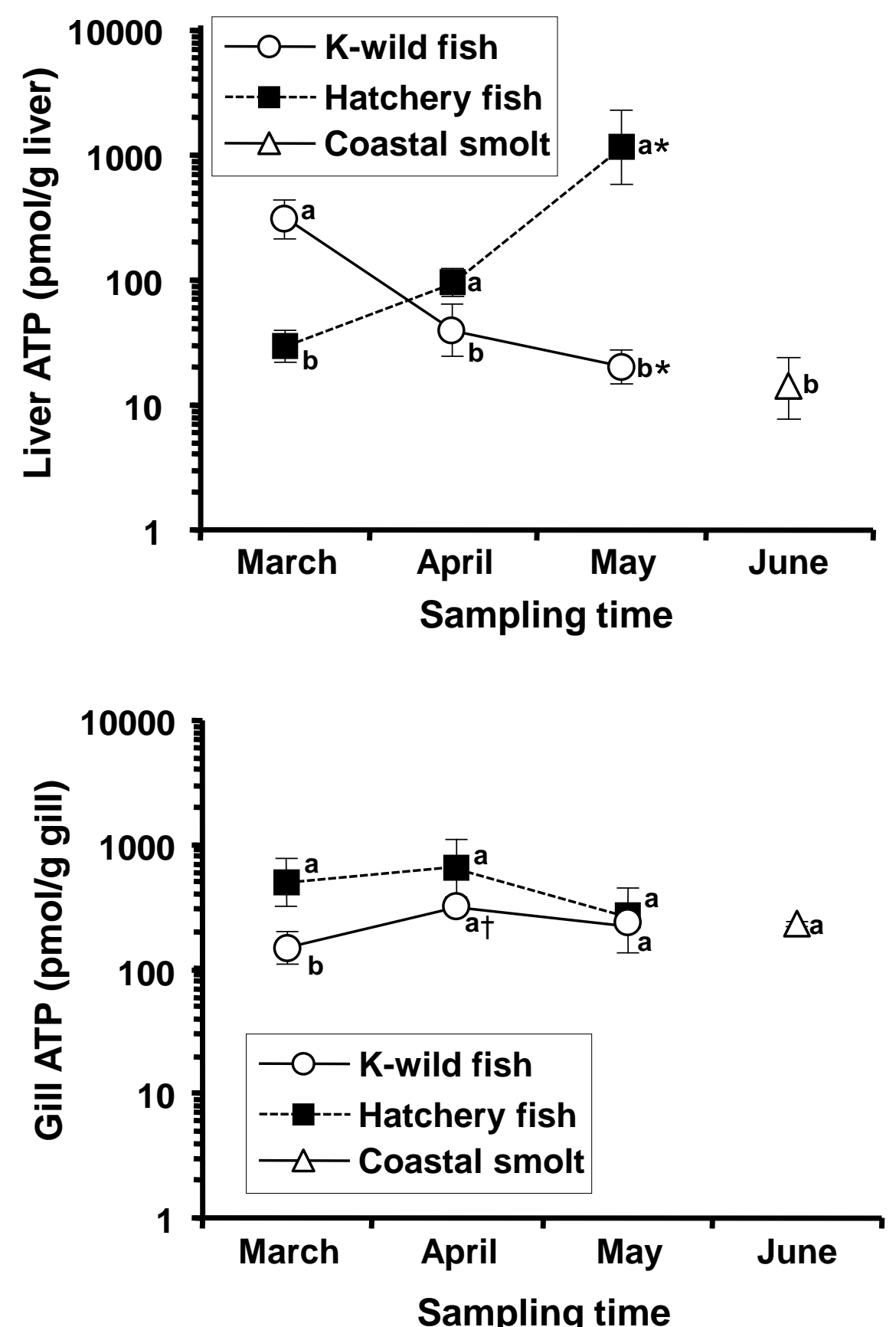

Fig.4 

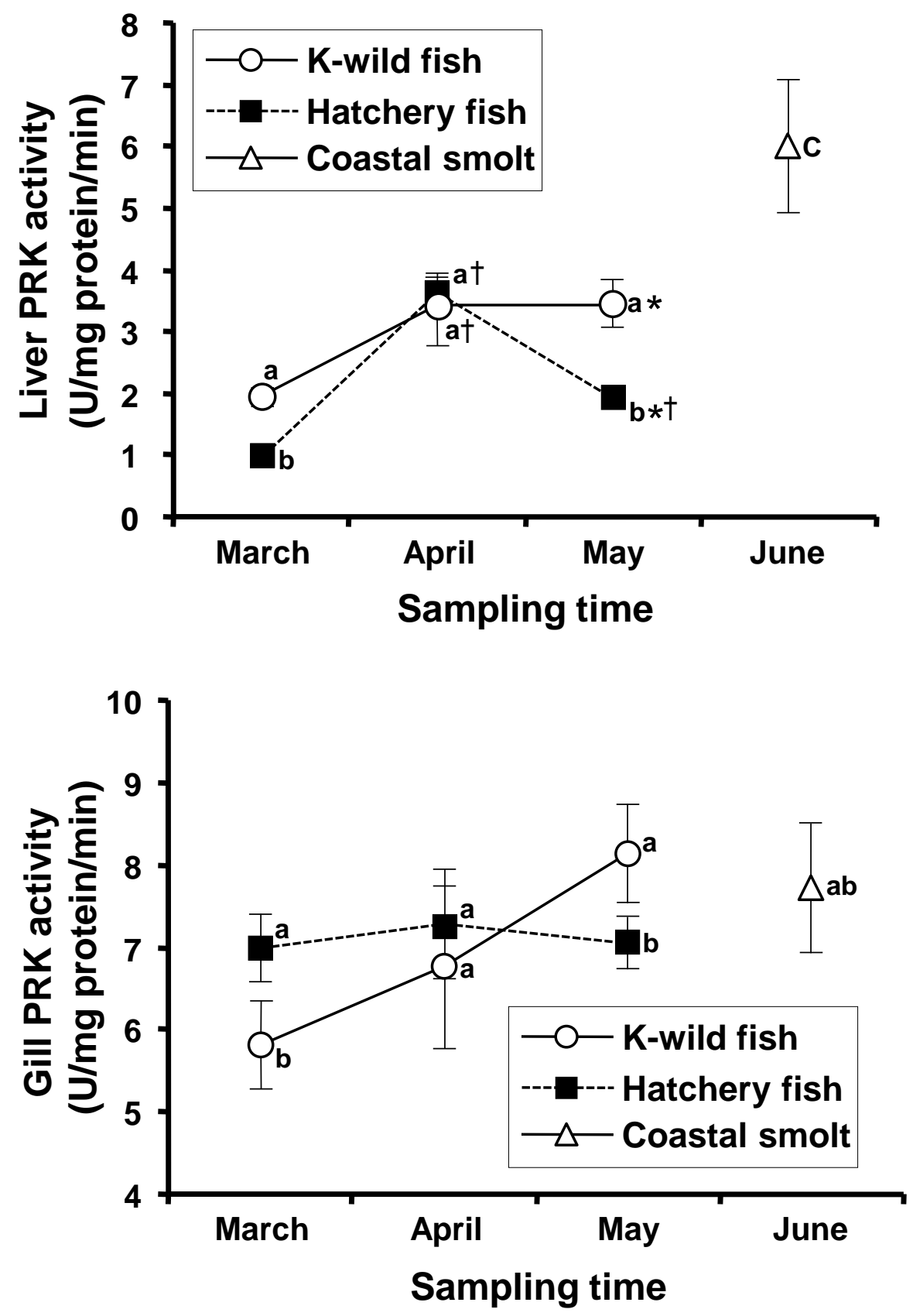

Fig.5 

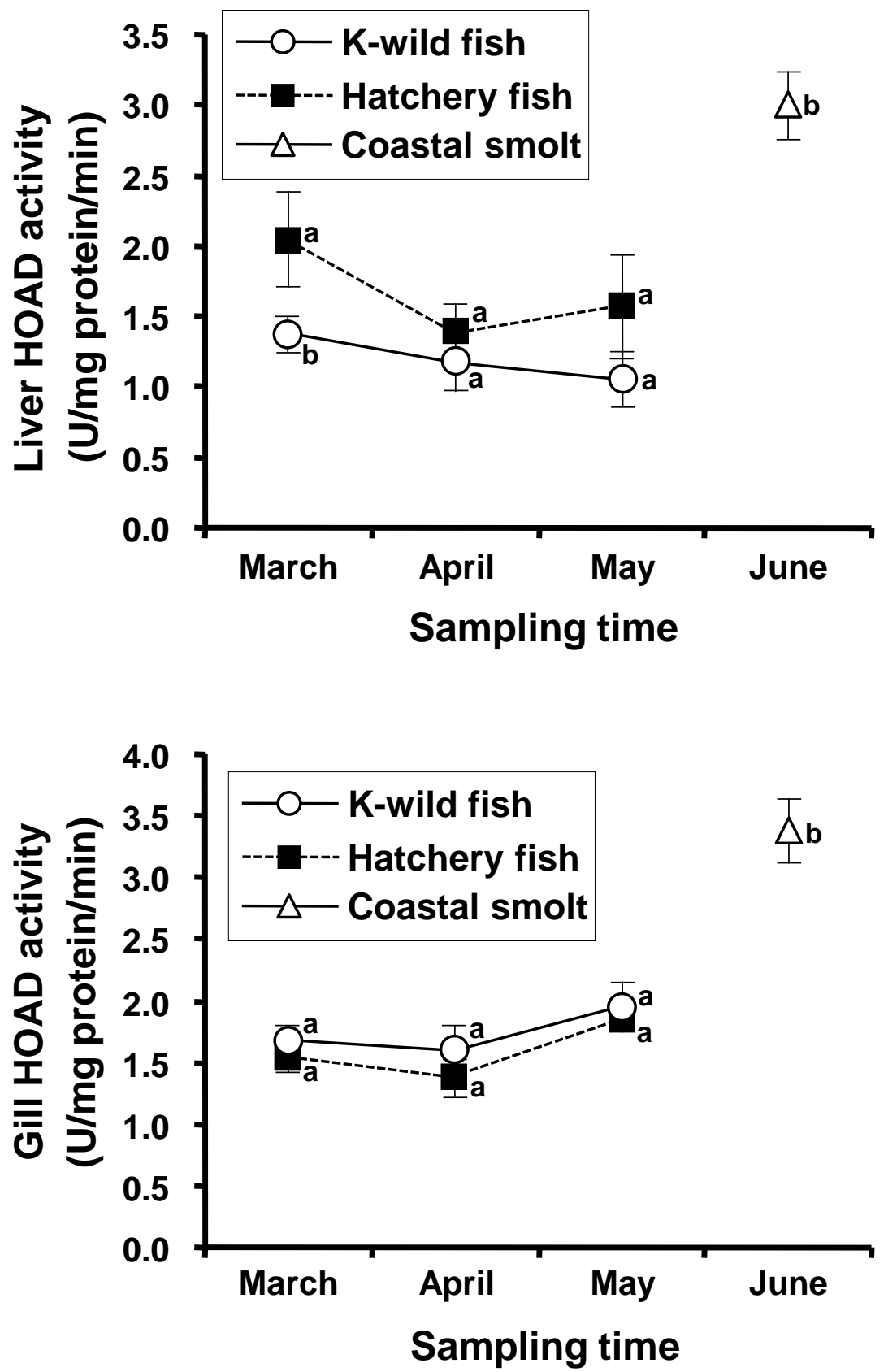

Fig.6 

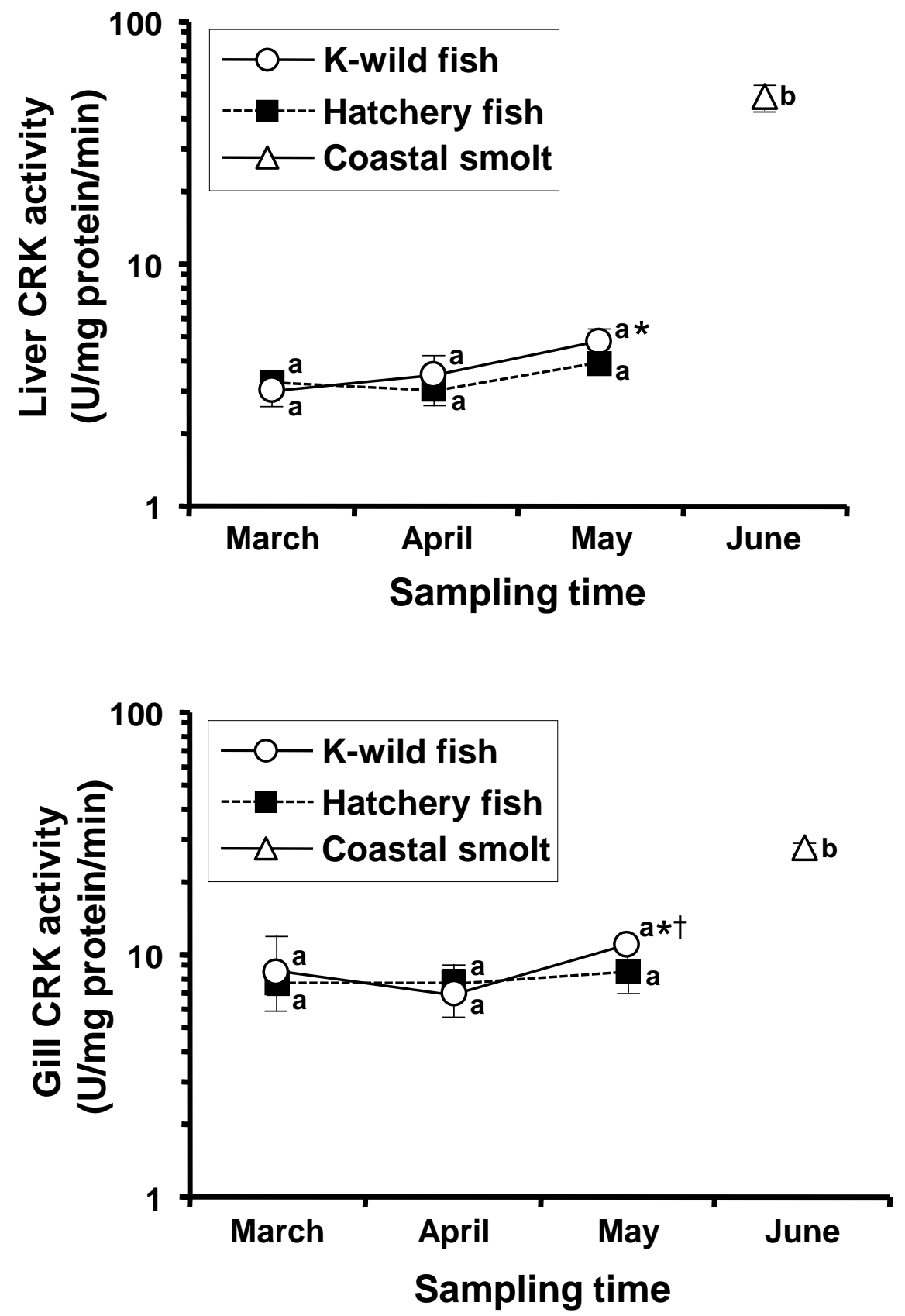

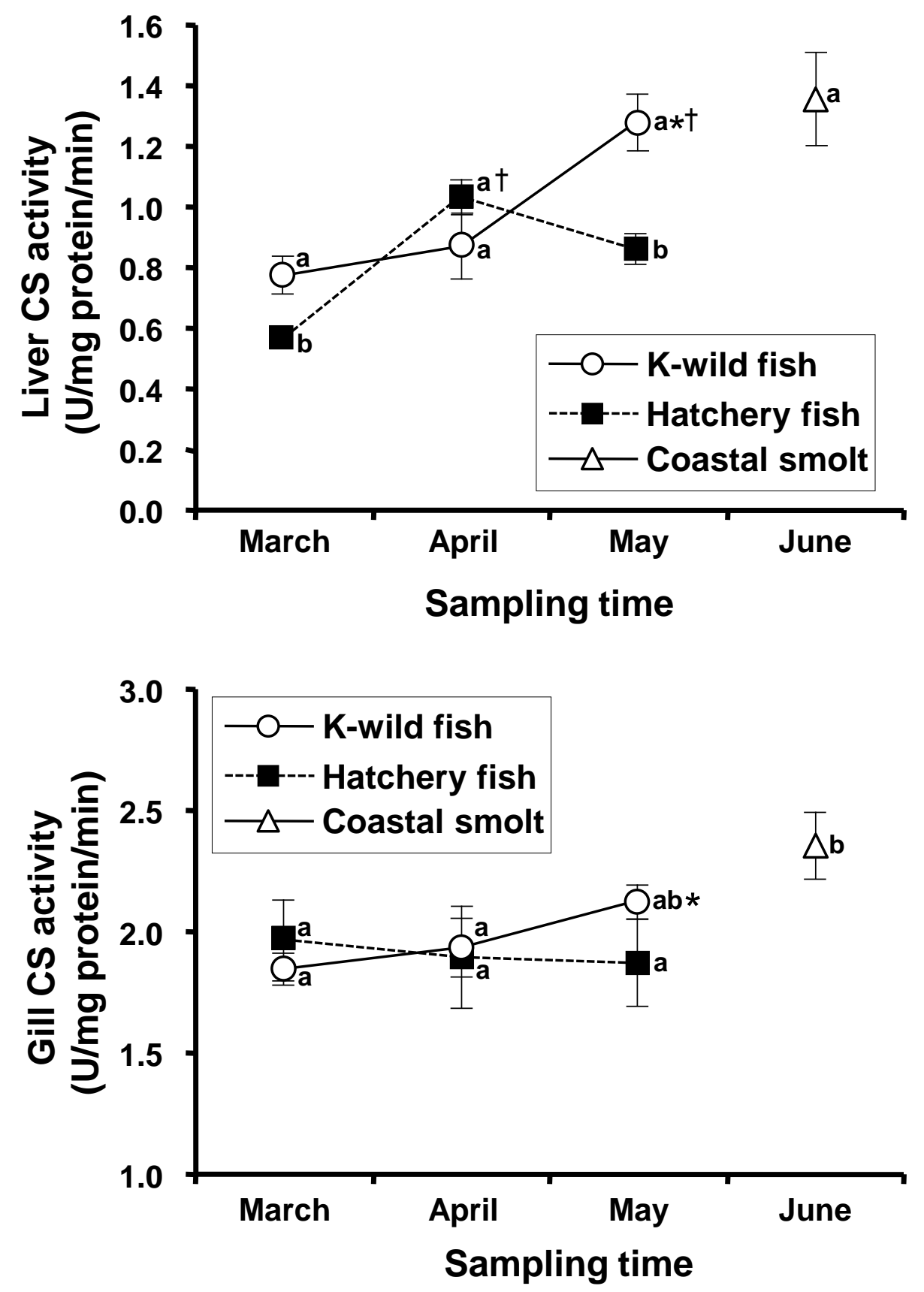

Fig.8 

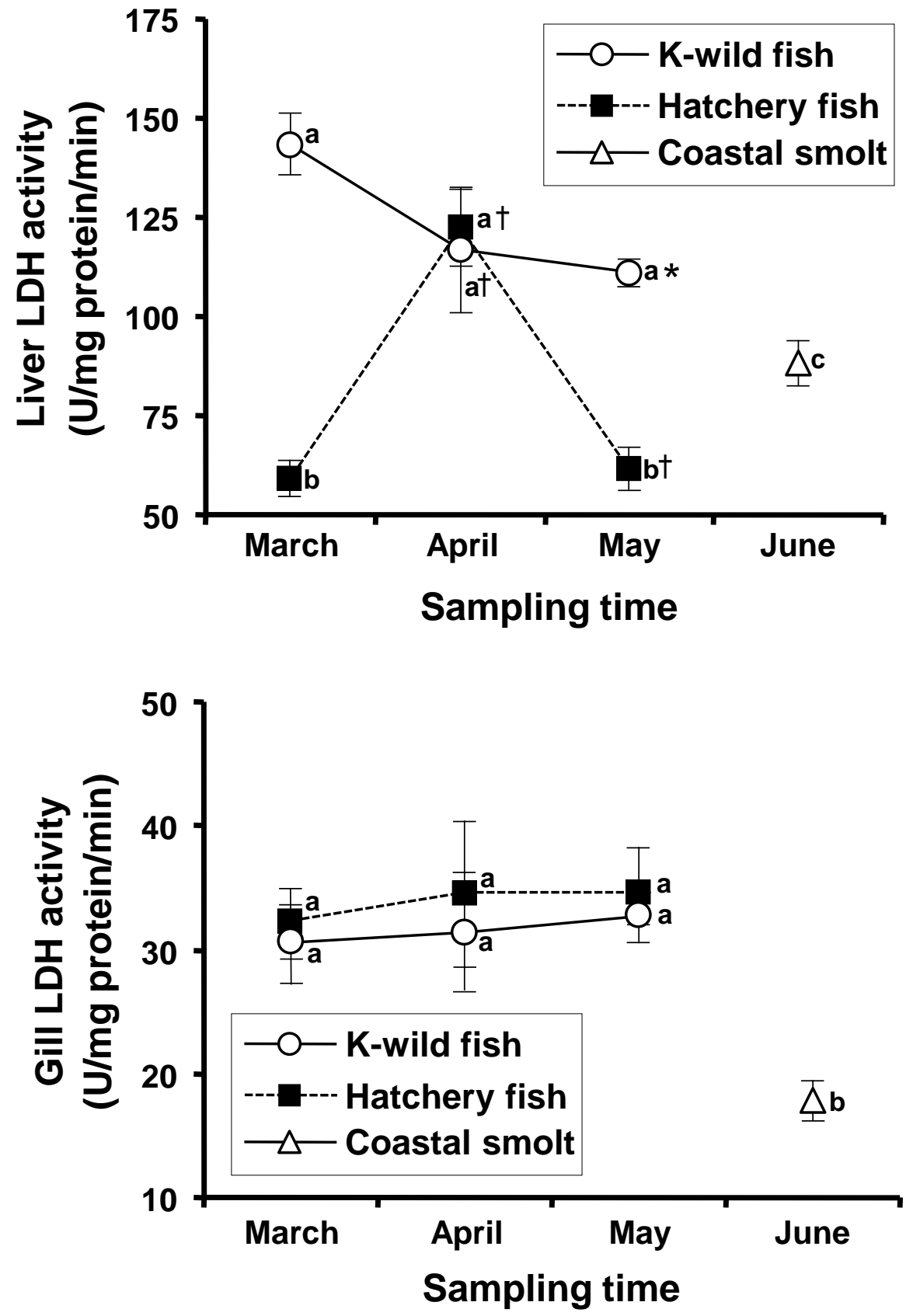

Fig.9 

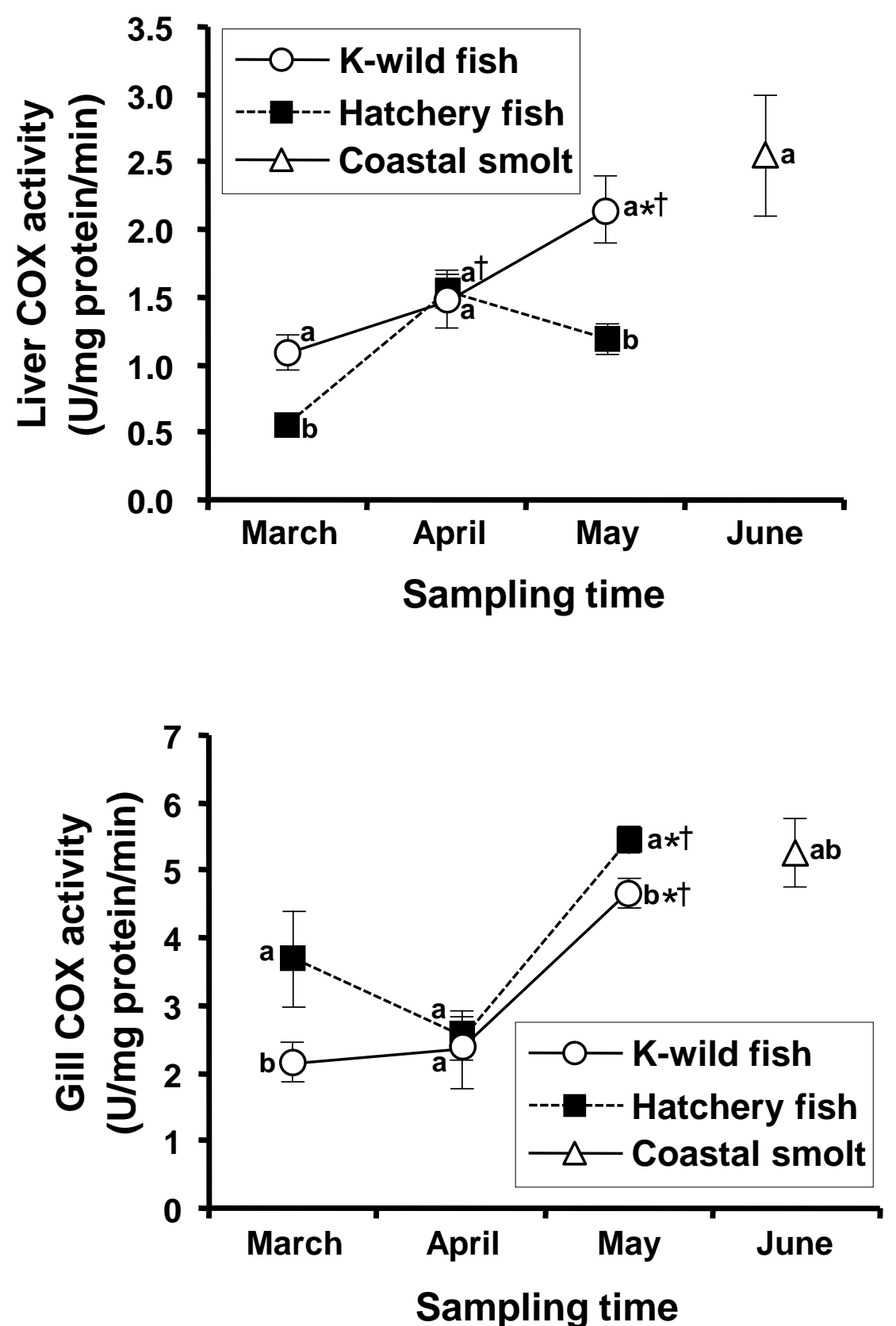

Fig. 10 

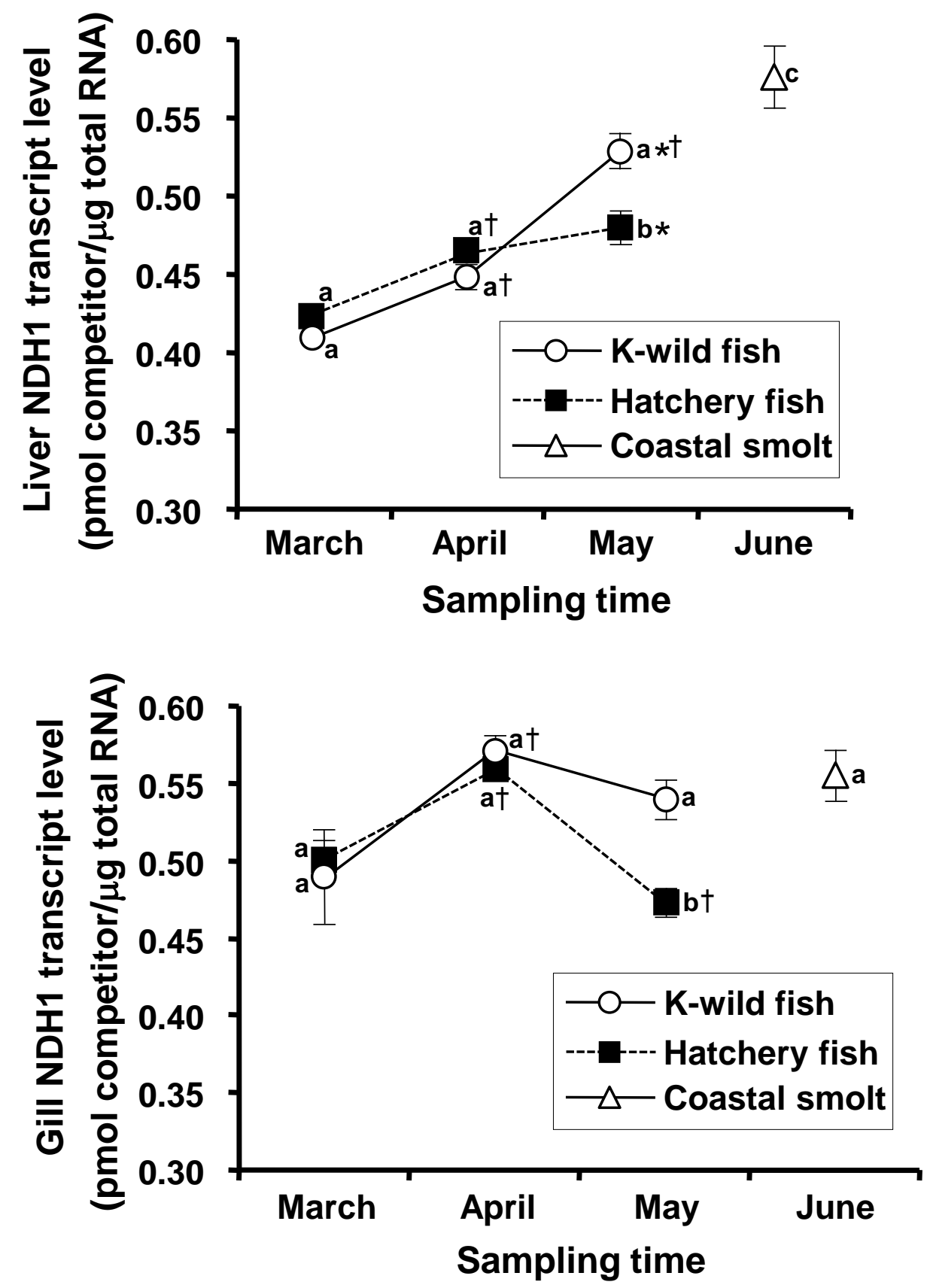

Fig.11 

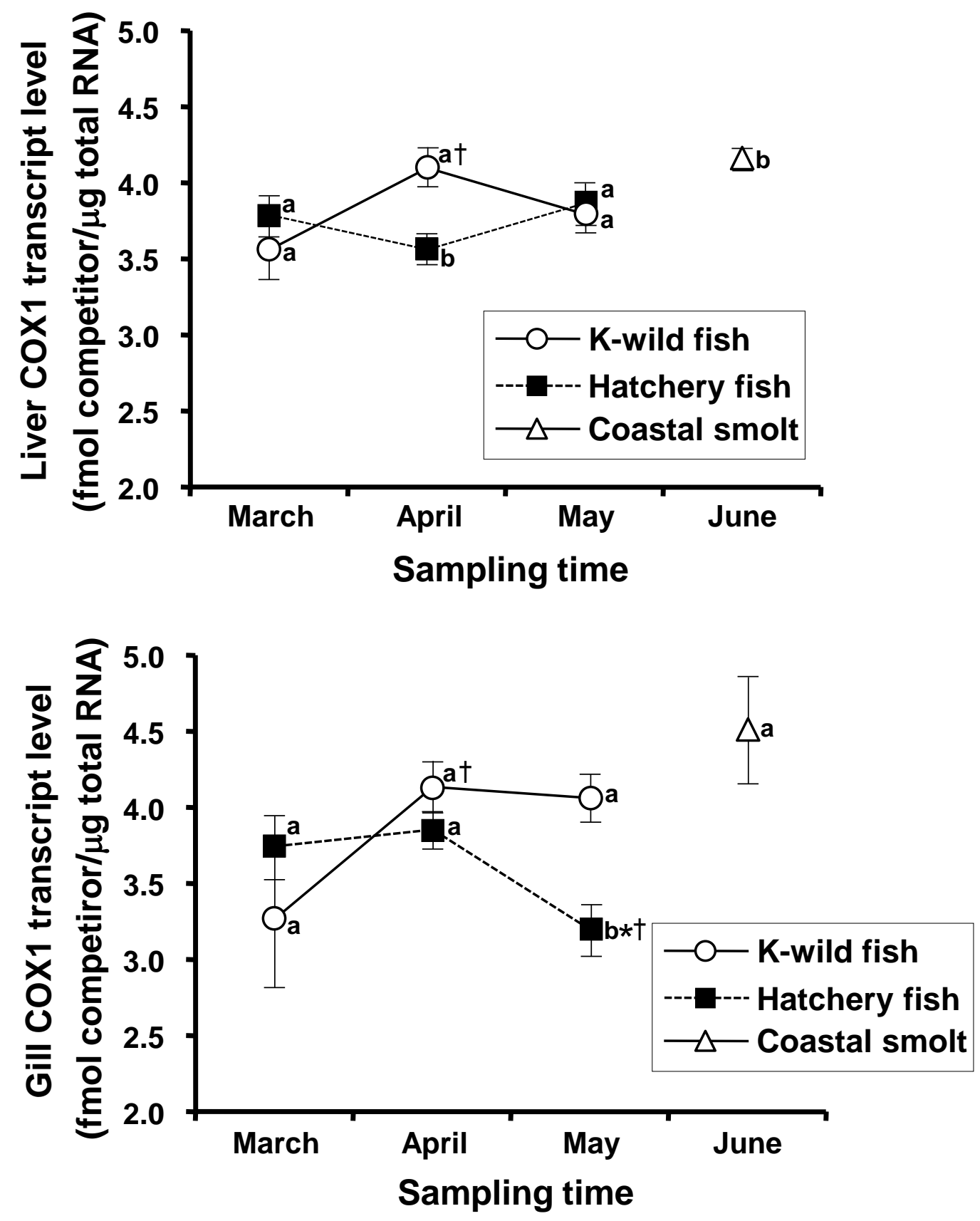

Fig.12 

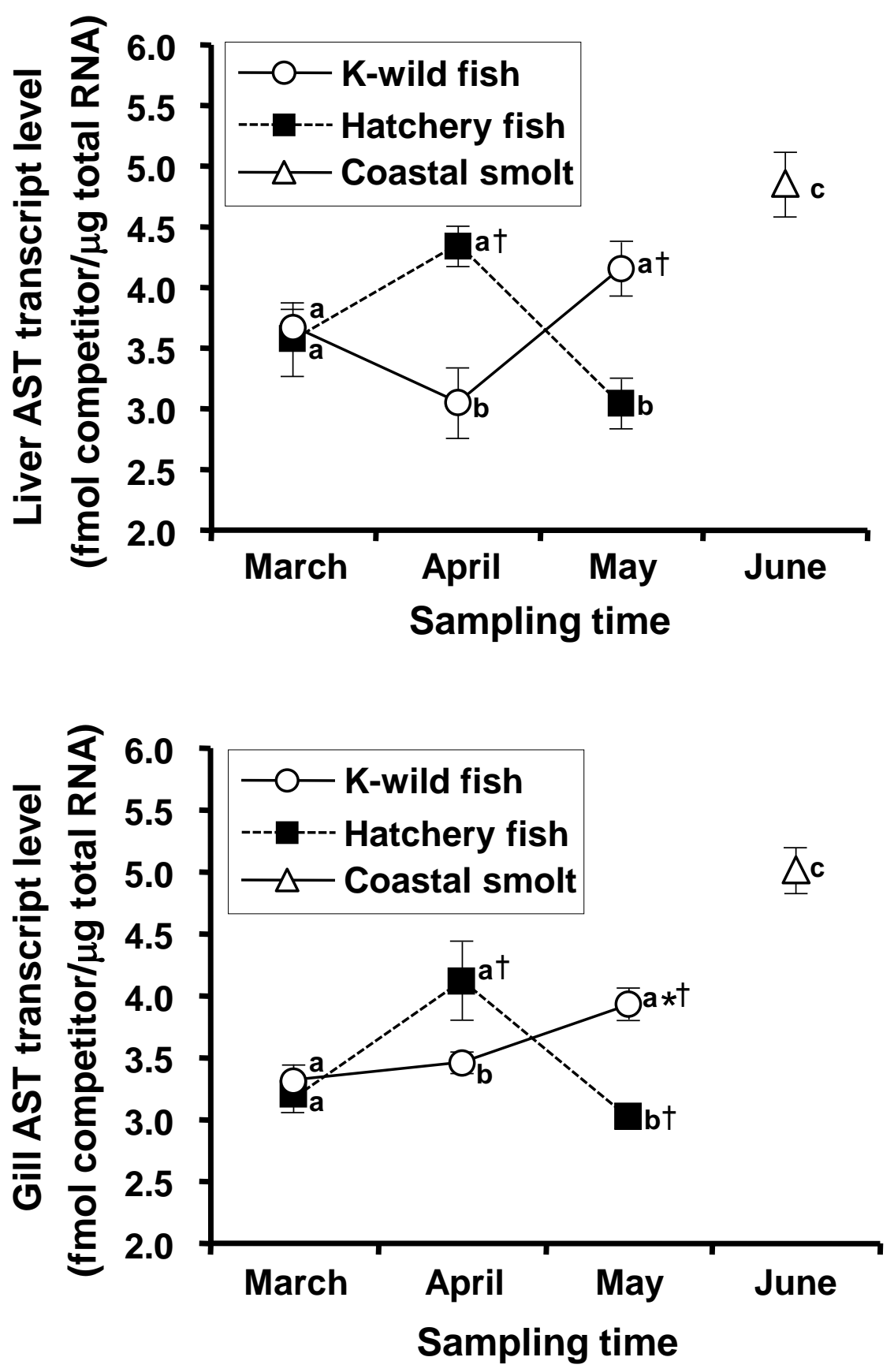

Fig.13 
Table 1

Primers used for competitive polymerase chain reaction analysis of NADH dehydrogenase subunit 1 (NDH1), COX subunit 1(COX1) and ATP synthase subunit 8 (ATS)

\begin{tabular}{ll}
\hline Primer name & Primer sequence \\
\hline NDH1 forward & 5'-AACCATTTCCTACGAAGT-3' \\
NDH1 reverse & 5'-TTCTGACTCTCCTTCTGT-3' \\
COX1forward & 5'-ACTTACAGACCGAAATCT-3' \\
COX1reverse & 5'-TGGTGGGCTCAAACGATA-3' \\
ATSforward & 5'-ATGCCCCAACTCAACCCCGC-3' \\
ATSreverse & 5'-TTAGTGTCATGGTCAGTTTC-3' \\
NDH1 competitor-making & 5'-TTCTGACTCTCCTTCTGTATGCTTTCTTGGGCTAC-3' \\
COX1 competitor-making & 5'-TGGTGGGCTCAAACGATAATACCAAAGCCTGGGA-3' \\
ATScompetitor-making & 5'-TTAGTGTCATGGTCAGTTTCGGAATAACAGTTAGGAAAA \\
\hline
\end{tabular}


Table 2

Mean fork length (FL), body weight (BW) and condition factor (CF) of masu salmon used in the present study.

\begin{tabular}{llcccc}
\hline Parameter & \multicolumn{1}{c}{ Fish (number) } & \multicolumn{3}{c}{ Month } \\
\cline { 3 - 6 } & & March & April & May & June \\
\hline FL (cm) & K-wild fish (10) & $11.4 \pm 0.35^{\mathrm{a}}$ & $11.8 \pm 0.24^{\mathrm{a}}$ & $13.0 \pm 0.20^{\mathrm{a} \dagger}$ & \\
& Hatchery fish (10) & $11.3 \pm 0.23^{\mathrm{a}}$ & $11.8 \pm 0.14^{\mathrm{a} \dagger}$ & $13.1 \pm 0.19^{\mathrm{a} \dagger}$ & \\
& Coastal smolt (7) & & & $13.6 \pm 0.39^{\mathrm{a}}$ \\
$\mathrm{BW}(\mathrm{g})$ & K-wild fish (10) & $15.7 \pm 1.46^{\mathrm{a}}$ & $18.3 \pm 1.10^{\mathrm{a} \dagger}$ & $23.2 \pm 1.03^{\mathrm{a} \dagger}$ & \\
& Hatchery fish (10) & $14.7 \pm 0.95^{\mathrm{a}}$ & $16.7 \pm 0.71^{\mathrm{a} \dagger}$ & $23.0 \pm 1.27^{\mathrm{a}}$ & \\
& Coastal smolt (7) & & & $26.6 \pm 1.61^{\mathrm{b}}$ \\
CF & K-wild fish (10) & $1.03 \pm 0.01^{\mathrm{a}}$ & $1.08 \pm 0.02^{\mathrm{a}}{ }^{\mathrm{b}}$ & $1.03 \pm 0.01^{\mathrm{a} \dagger}$ & \\
& Hatchery fish (10) & $0.98 \pm 0.01^{\mathrm{b}}$ & $0.99 \pm 0.02^{\mathrm{b}}$ & $1.01 \pm 0.02^{\mathrm{a}}$ & \\
& Coastal smolt (7) & & & & $1.06 \pm 0.04^{\mathrm{a}}$ \\
\hline
\end{tabular}

Different small alphabetical letters showed differences $(\mathrm{p}<0.05)$ in the value between K-wild and hatchery fish on March and April and among K-wild fish, hatchery fish and coastal smolt on May and June. The value with cross mark was different from the value of the same parameter a month before in the same group $(\mathrm{p}<0.05)$. 